\title{
Refining trace metal temperature proxies in cold-water scleractinian and stylasterid corals
}

\author{
Joseph A. Stewart ${ }^{\mathrm{a}, \mathrm{b}, \mathrm{c}, *}$, Laura F. Robinson ${ }^{\mathrm{a}}$, Russell D. Day ${ }^{\mathrm{c}, \mathrm{d}}$, Ivo Strawson ${ }^{\mathrm{a}}$, \\ Andrea Burke $^{\mathrm{b}}$, James W.B. Rae ${ }^{\mathrm{b}}$, Peter T. Spooner ${ }^{\mathrm{a}, \mathrm{f}}$, Ana Samperiz ${ }^{\mathrm{a}, \mathrm{e}}$, Peter J. Etnoyer ${ }^{\mathrm{g}}$, \\ Branwen Williams $^{\mathrm{h}}$, Adina Paytan ${ }^{\mathrm{i}}$, Melanie J. Leng ${ }^{\mathrm{j}, \mathrm{k}}$, Vreni Häussermann ${ }^{\mathrm{l}}$, \\ Leslie N. Wickes ${ }^{\mathrm{g}}$, Rachael Bratt ${ }^{\mathrm{a}}$, Helena Pryer ${ }^{\mathrm{a}}$ \\ a School of Earth Sci. Univ. of Bristol, Queens Road, Bristol, BS8 1RJ, UK \\ b School of Earth E' Environmental Sci., Univ. of St Andrews, KY16 9AL, UK \\ c National Institute of Standards and Technology, Chemical Science Division, Hollings Marine Laboratory, Charleston, SC, USA \\ d Marine Science and Nautical Training Academy (MANTA), 520 Folly Rd., Charleston, SC 29412, USA \\ e Cardiff University, School of Earth E' Ocean Sciences, Cardiff, CF10 3AT, UK \\ ${ }^{\mathrm{f}}$ Department of Earth Science, University College London, London, UK \\ g NOAA National Centers for Coastal Ocean Science, Charleston SC 29412, USA \\ h Keck Science Department, Claremont McKenna-Pitzer-Scripps Colleges, Claremont, CA 91711, USA \\ ${ }^{i}$ Institute of Marine Sci., University of California, Santa Cruz, Santa Cruz, CA 95064, USA \\ j British Geological Survey, Keyworth, Nottingham, NG12 5GG, UK \\ ${ }^{\mathrm{k}}$ School of Biosciences, University of Nottingham, Loughborough LE12 5RD, UK \\ ${ }^{1}$ Huinay Scientific Field Station, Pontificia Universidad Católica de Valparaíso, Escuela de Ciencias del Mar, Facultad de Recursos Naturales, Chile
}

\section{A R T I C L E I N F O}

\section{Article history:}

Received 7 February 2020

Received in revised form 7 June 2020

Accepted 8 June 2020

Available online $\mathrm{xxxx}$

Editor: L. Derry

\section{Keywords:}

Scleractinia

Stylasteridae

seawater temperature

$\mathrm{Li} / \mathrm{Mg}$

mineralogy

\begin{abstract}
A B S T R A C T
The $\mathrm{Li} / \mathrm{Mg}, \mathrm{Sr} / \mathrm{Ca}$ and oxygen isotopic $\left(\delta^{18} \mathrm{O}\right)$ compositions of many marine biogenic carbonates are sensitive to seawater temperature. Corals, as cosmopolitan marine taxa with carbonate skeletons that can be precisely dated, represent ideal hosts for these geochemical proxies. However, efforts to calibrate and refine temperature proxies in cold-water corals $\left(<20^{\circ} \mathrm{C}\right)$ remain limited. Here we present skeletal $\mathrm{Li} / \mathrm{Mg}, \mathrm{Sr} / \mathrm{Ca}, \delta^{18} \mathrm{O}$ and carbon isotope $\left(\delta^{13} \mathrm{C}\right)$ data from live-collected specimens of aragonitic scleractinian corals (Balanophyllia, Caryophyllia, Desmophyllum, Enallopsammia, Flabellum, Lophelia, and Vaughanella), both aragonitic and high-Mg calcitic stylasterid genera (Stylaster and Errina), and shallow-water high-Mg calcite crustose coralline algae (Lithophyllum, Hydrolithon, and Neogoniolithon). We interpret these data in conjunction with results from previously explored taxa including aragonitic zooxanthellate scleractinia and foraminifera, and high- $\mathrm{Mg}$ calcite octocorals. We show that $\mathrm{Li} / \mathrm{Mg}$ ratios covary most strongly with seawater temperature, both for aragonitic and high-Mg calcitic taxa, making for reliable and universal seawater temperature proxies. Combining all of our biogenic aragonitic Li/Mg data with previous calibration efforts we report a refined relationship to temperature: $\mathrm{Li} / \mathrm{Mg}_{\text {All Aragonite }}=5.42 \exp (-0.050 \times$ $\left.T\left({ }^{\circ} \mathrm{C}\right)\right)\left(R^{2}=0.97\right)$. This calibration now permits paleo-temperature reconstruction to better than $\pm 3.4^{\circ} \mathrm{C}$ (95\% prediction intervals) across biogenic aragonites, regardless of taxon, from 0 to $30^{\circ} \mathrm{C}$. For taxa in this study, aragonitic stylasterid $\mathrm{Li} / \mathrm{Mg}$ offers the most robust temperature proxy ( $\mathrm{Li} / \mathrm{Mg}_{\text {Stylasterid (Arag) }}$ $\left.=5.64 \exp \left(-0.046 \times T\left({ }^{\circ} \mathrm{C}\right)\right)\left(R^{2}=0.95\right)\right)$ with a reproducibility of $\pm 2.3^{\circ} \mathrm{C}$. For the first time, we show that high-Mg calcites have a similar exponential relationship with temperature, but with a lower intercept value $\left(\mathrm{Li} / \mathrm{Mg}=0.63 \exp \left(-0.050 \times T\left({ }^{\circ} \mathrm{C}\right)\left(R^{2}=0.92\right)\right)\right.$. This calibration opens the possibility of temperature reconstruction using high-Mg calcite corals and coralline algae. The commonality in the relationship between $\mathrm{Li} / \mathrm{Mg}$ and temperature transcends phylogeny and suggests a similar abiogenic trace metal incorporation mechanism.
\end{abstract}

(c) 2020 The Author(s). Published by Elsevier B.V. This is an open access article under the CC BY license (http://creativecommons.org/licenses/by/4.0/).

\section{Introduction}

* Corresponding author at: School of Earth Sci. Univ. of Bristol, Queens Road, Bristol, BS8 1RJ, UK.

E-mail address: joseph.stewart@bristol.ac.uk (J.A. Stewart).
Understanding the linkages between ocean circulation, carbon cycling, and rapid climate change on geologic and histori- 
cal timescales remains a key goal of paleoceanographic research (Broecker, 1982). Paleo-seawater temperature is a hydrographic variable vital to our interpretation of these ocean-climate interactions (Thiagarajan et al., 2014). Much attention has therefore been given to the development of geochemical paleo-temperature proxies in marine carbonates to extend temperature timeseries beyond the range of instrumental records (Anand et al., 2003; Case et al., 2010; Spooner et al., 2016). Deep-sea sediment cores remain a popular archive for obtaining ancient biogenic carbonate material (e.g. (Poggemann et al., 2017; Roberts et al., 2016)). However, impaired age control often limits use of these records for understanding the leads and lags of the climate system on millennial timescales or shorter. Therefore, robust temperature proxies from archives with precise age control are much needed.

Corals occupy a wide geographic and bathymetric range (Roberts et al., 2006). They can be accurately and precisely dated by radiometric methods (Cheng et al., 2000) or annual growth band counting (Knutson et al., 1972) making them exciting targets for paleoceanographic research. Selected trace metal and stable isotopic ratios in marine carbonates have been shown to vary as a function of seawater temperature including: $\mathrm{Sr} / \mathrm{Ca}$ (Beck et al., 1992; Cohen et al., 2001), Li/Ca (Hall and Chan, 2004; Marriott et al., 2004), Mg/Ca (Anand et al., 2003; Case et al., 2010), and $\delta^{18} \mathrm{O}$ (Cobb et al., 2003; Gagan et al., 2012). Such temperature proxies have been used to reconstruct temperature on sub-annual to millennial timescales (Cohen et al., 2001; McCulloch et al., 1999).

Scleractinian corals (Subclass Hexacorallia: Order Scleractinia) calcify from an extracellular calcifying fluid (ECF) that is semirestricted from ambient seawater (Sinclair and Risk, 2006). The chemistry of this ECF is modified via the Ca-ATPase pump, raising internal $\mathrm{pH}$ and saturation state to promote precipitation of skeletal calcium carbonate (Al-Horani et al., 2003). Such changes to internal seawater can impact skeletal chemistry independent of seawater temperature. For instance, the $\delta^{13} \mathrm{C}$ and $\delta^{18} \mathrm{O}$ composition of the coral skeleton is impacted by kinetic isotope effects during hydration and hydroxylation of $\mathrm{CO}_{2}$ (Guo, 2020; McConnaughey, 1989), $\mathrm{pH}$ dependent dissolved inorganic carbon speciation (i.e. $\mathrm{HCO}_{3}^{-}$to ${ }^{18}$ O-depleted $\mathrm{CO}_{3}^{2-}$; Adkins et al., 2003), and carbonic anhydrase activity (Chen et al., 2018). Skeletal trace metal compositions can be similarly modified by the balance between carbonate precipitation, direct seawater leakage, and ion pumping into the ECF. Through Rayleigh fractionation and/or growth entrapment, ions can become either depleted or enriched in the ECF (relative to $C a)$ depending on their partition coefficient $(D)$ into the carbonate lattice as calcification progresses (e.g. $D_{\mathrm{Sr}}=\mathrm{Sr} / \mathrm{Ca}_{\text {carbonate }} /$ $\mathrm{Sr} / \mathrm{Ca}_{\text {seawater }}>1$; (Gaetani et al., 2011; Gagnon et al., 2007; Watson, 2004)). Trace element ratios may therefore be impacted by the calcification process, driving variations between coral species, colonies, and even individuals, thus hindering their use as temperature monitors (Chen et al., 2018; Gagan et al., 2012; Gagnon et al., 2007). Paired coral U/Ca ratios have been used to correct $\mathrm{Sr} / \mathrm{Ca}$ values for growth rate effects, yielding a more robust relationship with seawater temperature (DeCarlo et al., 2016). However, this $\mathrm{Sr}-\mathrm{U}$ approach is only applicable to large, growth-banded, shallowwater corals, from which seasonally resolved records can be obtained to characterise the $\mathrm{Sr}: \mathrm{U}$ relationship for each individual (Ross et al., 2019). Alternative approaches are therefore required for developing robust temperature proxies in smaller cold-water coral taxa.

Coral $\mathrm{Mg} / \mathrm{Ca}$ and $\mathrm{Li} / \mathrm{Ca}$ ratios alone have complex, but contrasting, relationships with calcification temperature. Studies show that skeletal $\mathrm{Mg} / \mathrm{Ca}$ has a positive correlation with temperature (Hathorne et al., 2013a), while others report this correlation to be poor (Case et al., 2010; Montagna et al., 2014)). Conversely, coral Li/Ca has a weak negative correlation with temperature (Case et al., 2010). With similar partition coefficients (both $D_{\mathrm{Li}}$ and $D_{\mathrm{Mg}}$ $\ll 1$ ) however, $\mathrm{Li} / \mathrm{Ca}$ and $\mathrm{Mg} / \mathrm{Ca}$ are similarly impacted by calcification processes (Marchitto et al., 2018). Thus the ratio of coral $\mathrm{Li} / \mathrm{Mg}$ has great promise; preserving the temperature dependency of these elements while minimising growth-rate effects (Case et al., 2010). A universal $\mathrm{Li} / \mathrm{Mg}$ relationship to temperature appears robust across published data for both zooxanthellate and azooxanthellate scleractinia (Andersson et al., 2020; Case et al., 2010; Cuny-Guirriec et al., 2019; Fowell et al., 2016; Hathorne et al., 2013a; Montagna et al., 2014; Raddatz et al., 2013; Ross et al., 2019) and also aragonitic foraminifera (Hoeglundina elegans; Bryan and Marchitto, 2008; Hall and Chan, 2004; Marchitto et al., 2018) (Fig. 1A). This recalculated relationship is described by the equation,

$$
\begin{aligned}
& \mathrm{Li} / \mathrm{Mg}_{\text {All Arag (published) }}=5.27[ \pm 0.06] \mathrm{e}^{-0.049[ \pm 0.001] \times T\left({ }^{\circ} \mathrm{C}\right)} \\
& \left(R^{2}=0.96 ;[ \pm \mathrm{SE}]\right)
\end{aligned}
$$

and is based on $\mathrm{Li} / \mathrm{Mg}$ data compiled from the literature that we now adjust for interlaboratory analytical offsets (see Methods and Supplementary Information). More than three quarters of the data characterising this $\mathrm{Li} / \mathrm{Mg}$ relationship to seawater temperature however come from shallow-water coral specimens harbouring zooxanthellae (Fowell et al., 2016; Hathorne et al., 2013a; Montagna et al., 2014; Ross et al., 2019), with few observations obtained from azooxanthellate deep-water taxa (Case et al., 2010; Cuny-Guirriec et al., 2019; Montagna et al., 2014; Raddatz et al., 2013). Fewer still of these samples are from locations with wellcharacterised temperature (Case et al., 2010). Full characterisation of this relationship across multiple cosmopolitan cold-water coral taxa $\left(<20^{\circ} \mathrm{C}\right)$ from localities with well-documented hydrography is therefore much needed. Cold-water corals are known to possess large heterogeneities in microstructural chemistry, with centres of calcification (COCs) being particularly enriched in $\mathrm{Li}$ and $\mathrm{Mg}$ and depleted $\delta^{13} \mathrm{C}$ and $\delta^{18} \mathrm{O}$ (Adkins et al., 2003; Anagnostou et al., 2011; Chen et al., 2018; Correa et al., 2010; Gagnon et al., 2007; Stewart et al., 2016). It is important therefore to ensure that sampling of such corals is reproducible and not unduly biased by microstructures.

A second important, but poorly studied, deep-water coral family is the Stylasteridae (Class Hydrozoa: Order Anthoathecata; Fig. 2). These Hydrozoan corals differ significantly from scleractinian corals in their ability to precipitate calcium carbonate skeletons of either aragonite, high-Mg calcite, or in some cases, both polymorphs (Cairns, 2011). Predicting the response of marine calcifiers to future anthropogenic change (e.g. ocean acidification and/or thermal stress) is critical and requires insight into the biocalcification processes of both aragonitic and high-Mg calcitic organisms from skeletal geochemistry (Donald et al., 2017). A recent study shows that stylasterid coral skeletal $\delta^{18} \mathrm{O}$ remains relatively close to equilibrium with seawater and is thus minimally impacted by growth-rate effects and well-correlated with seawater temperature (Samperiz et al., 2020). Yet, there remains no study to date characterising trace metal compositions of either aragonitic or calcitic stylasterid corals, hence their paleoceanographic proxy potential and biocalcification mechanisms remain poorly understood.

The temperature dependency of trace metals in high-Mg calcites is less well-constrained than it is in aragonitic calcifiers. Exploratory work into high-Mg calcite crustose coralline algae (CCA) grown in laboratory culture (Clathromorphum compactum; 6 to $13^{\circ} \mathrm{C}$ ) suggest that $\mathrm{Li} / \mathrm{Mg}$ in high-Mg calcites may also be related to temperature (Fig. 1A; Anagnostou et al., 2019). However, this result contrasts with $\mathrm{Li} / \mathrm{Mg}$ values measured in wild-collected high-Mg calcitic coral Corallium rubrum (Octocorallia) which are suggested to have little coherent relationship with seawater temperature (Fig. 1A; Chaabane et al., 2019). Without high-Mg calcite 


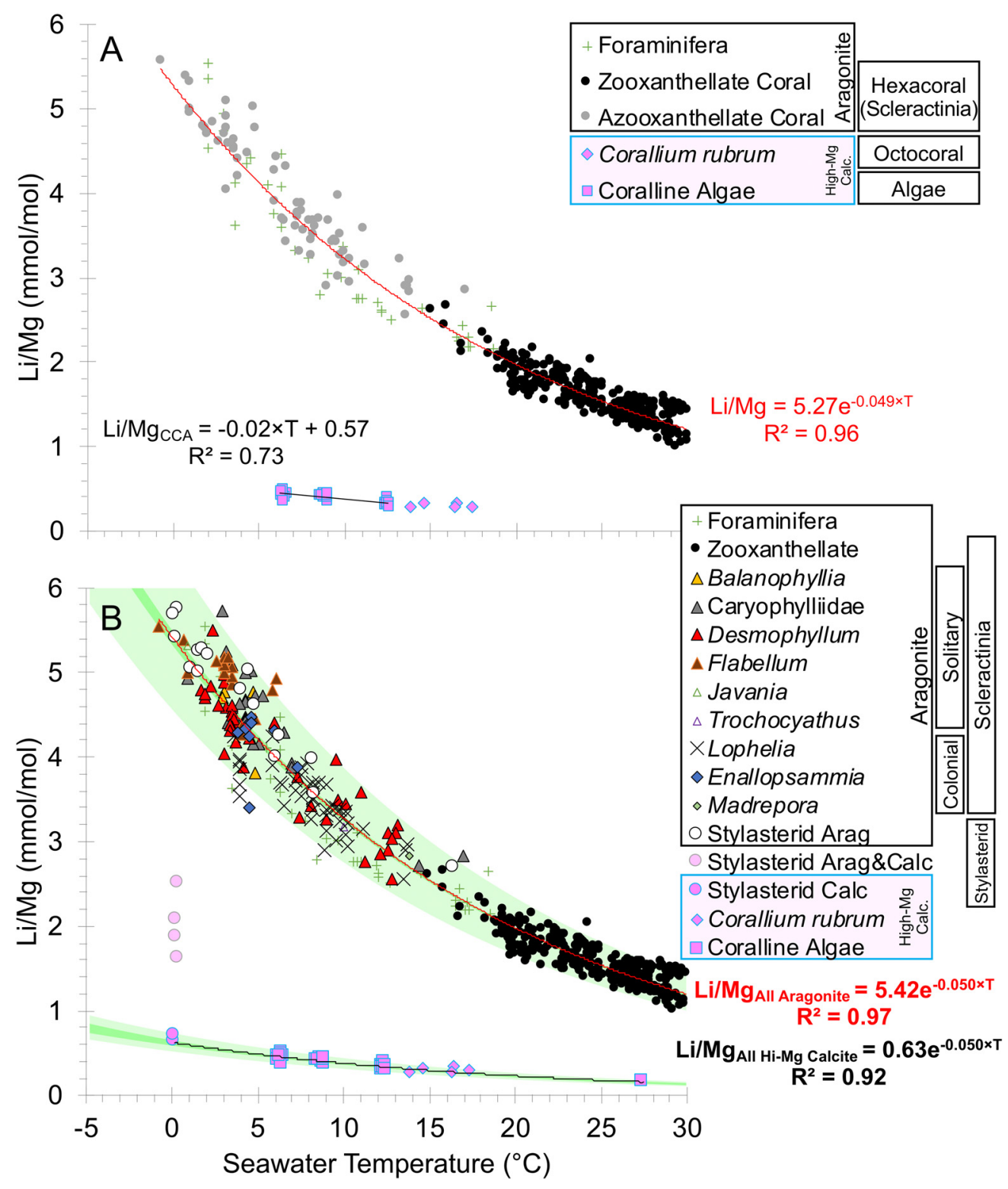

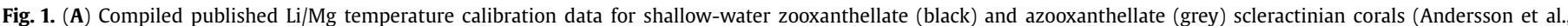

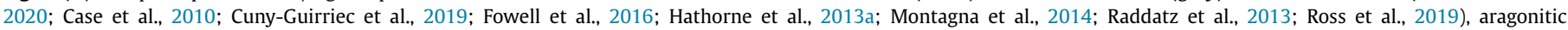

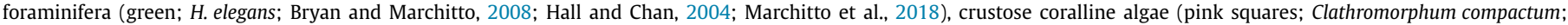

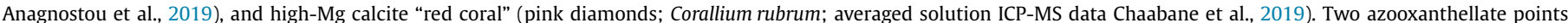

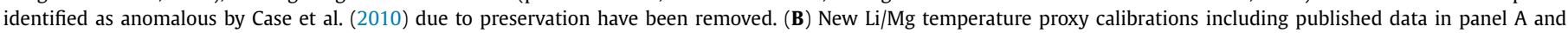

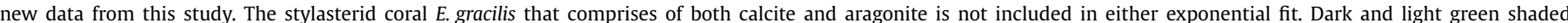

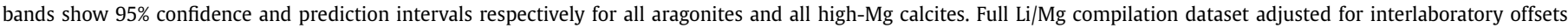

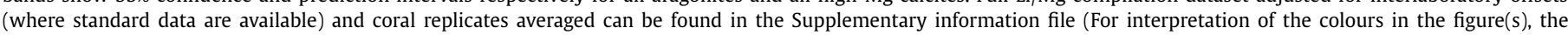
reader is referred to the web version of this article.)

samples from a greater range of temperatures it remains unclear if the $\mathrm{Li} / \mathrm{Mg}$ relationship to temperature is linear (Anagnostou et al., 2019), exponential (e.g. scleractinia; Montagna et al., 2014), or indeed absent (Chaabane et al., 2019) in this group of organisms.

To assess temperature proxies within different marine carbonate mineralogies, we present skeletal $\mathrm{Li} / \mathrm{Mg}, \mathrm{Sr} / \mathrm{Ca}$, and $\delta^{18} \mathrm{O}$ data obtained from modern cold-water coral calyxes from seawater temperatures ranging from 0 to $16^{\circ} \mathrm{C}$. These specimens comprise 7 genera of common deep-water scleractinia as well as two genera of stylasterid corals (Stylaster and Errina) that represent all three modes of stylasterid skeletal mineralogy: (i) solely aragonite, (ii) both aragonite and high-Mg calcite, and (iii) solely high-Mg calcite (Cairns and Macintyre, 1992; Samperiz et al., 2020). We present data from the same stylasterid specimens for which $\delta^{18} \mathrm{O}$ has been previously characterised (Samperiz et al., 2020) for com- parison with our trace metal data. We complement these coral sample sets, with CCA collected from tropical surface waters, expanding the range of high-Mg calcite skeletons to include warmer water specimens $\left(\sim 27^{\circ} \mathrm{C}\right)$. We use skeletal $\delta^{13} \mathrm{C}$ to assess biocalcification and microstructural variability in replicate samples. We critically assess the reliability of each proxy and its applicability for reconstructing paleo-seawater temperature.

\section{Methodology}

\subsection{Samples and hydrographic data}

More than 100 coral samples were collected from the Labrador Sea (RRS Discovery DY081), Northeast Atlantic (RRS James Cook JC136), Equatorial Atlantic (RRS James Cook JC094), Drake Pas- 


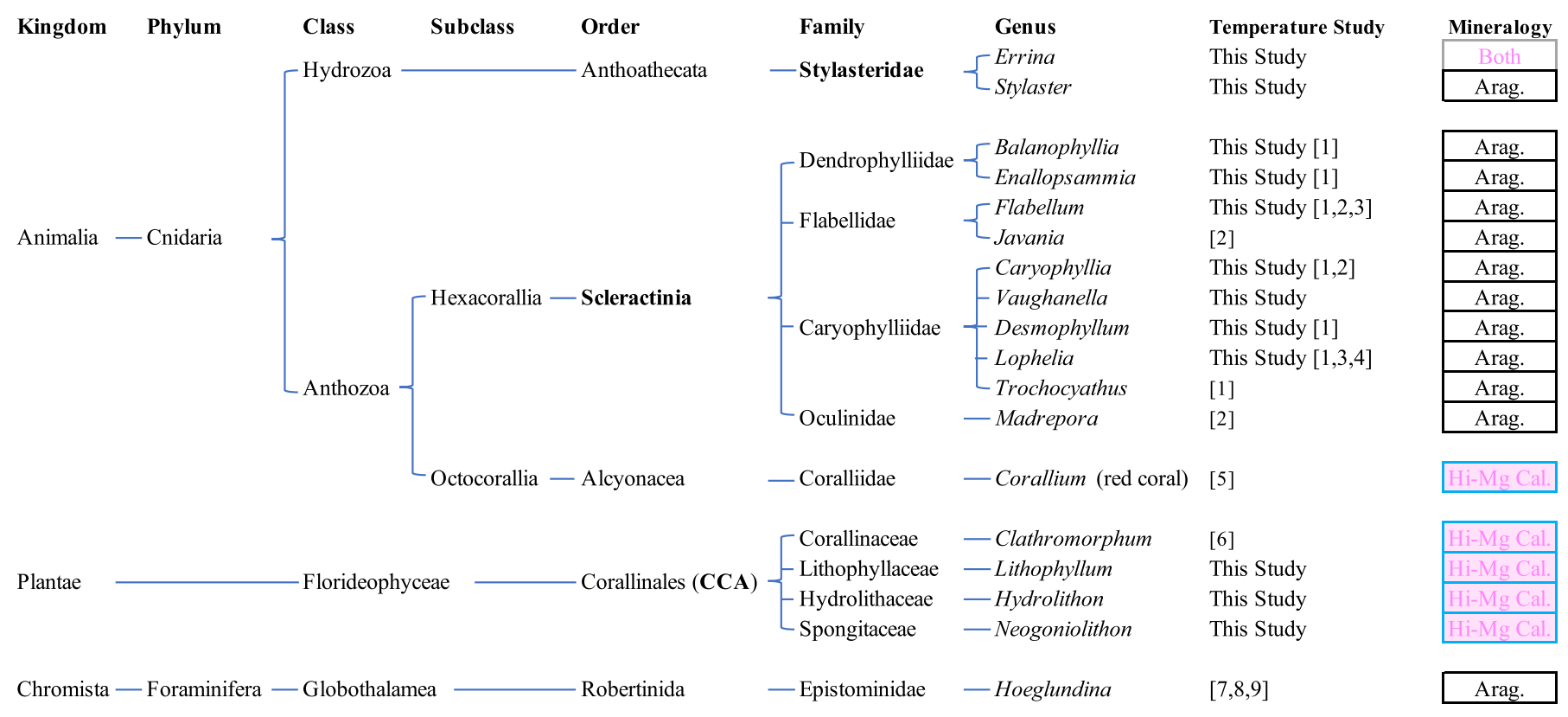

[1]Case et al., 2010, [2]Cuny-Guirriec, et al 2019, [3]Montagna et al., 2014, [4]Raddatz et al., 2013, [5]Chaabane et al., 2019, [6]Anagnostou et al., 2019, [7]Hall \& Chan 2004, [8]Bryan \& Marchitto 2008, [9]Marchitto et al., 2018

Fig. 2. Phylogeny and skeletal mineralogy (Aragonite, high-Mg calcite or both polymorphs) of carbonates in this study.

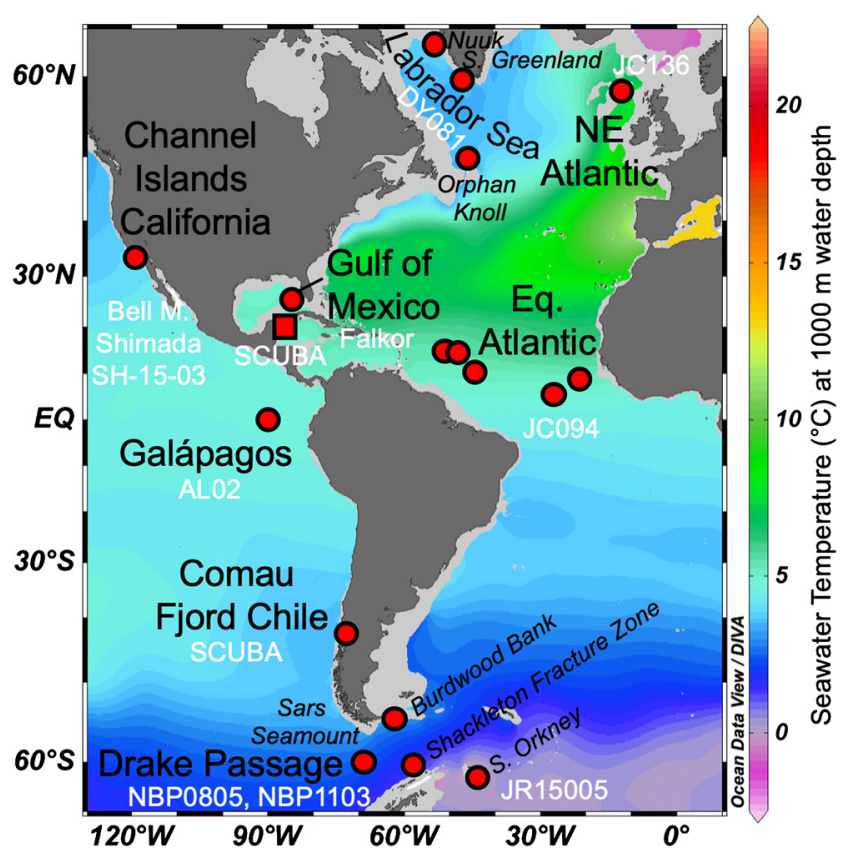

Fig. 3. Location of modern coral (circles) and coralline algae (square) samples used in this study with respective cruise identifiers (white text). Base map shows World Ocean Atlas gridded seawater temperature at 1000 m (Locarnini et al., 2013).

sage (R/V Nathaniel B. Palmer 1103 and 0805; RRS James Clark Ross JR15005), Channel Islands National Marine Sanctuary (CINMS; NOAA ship Bell M. Shimada SH-15-03), Gulf of Mexico (R/V Falkor FK006c), Galápagos Archipelago (Alucia Cruise AL1508) and Comau Fjord (Huinay Field Station Chile; retrieved by SCUBA) (Fig. 3). Coral samples belonged to (i) Scleractinia: Balanophyllia, Caryophyllia, Desmophyllum, Enallopsammia, Flabellum, Lophelia, and Vaughanella and (ii) Stylasteridae: Stylaster and Errina genera (Fig. 2). We also include 14 CCA samples from three genera (Lithophyllum $n=2$, Hydrolithon $n=3$, Neogoniolithon $n=9$ ) collected by SCUBA from offshore Puerto Morelos, near the Mesoamerican
Reef (Caribbean Sea). For calibration purposes, the average measurement for each CCA genus at this site is used to avoid biasing the weight of observations towards high temperatures. With the exception of two stylasterid individuals (which appear to have "pristine" preservation), all samples in this study were collected alive, with associated organic tissue, thus ensuring paired hydrographic data are representative.

Genera Caryophyllia and Vaughanella, within the scleractinian corals, are morphologically similar and from the same taxonomic family (Fig. 2). We therefore group these samples under family Caryophylliidae for discussion. We also group stylasterids by mineralogy (i) solely aragonite (E. antarctica, E. boschmai, E. altispina, S. robustus, S. densicaulis, S. erubescens, S. ibericus, S. marenzelli), (ii) both aragonite and high-Mg calcite (E. gracilis; 4 to 8 weight percent high-Mg calcite), and (iii) solely high-Mg calcite (E. laterorifa) Cairns and Macintyre, 1992; Samperiz et al., 2020.

Where possible seawater temperature data were taken from co-located remotely operated vehicle or CTD (conductivity, temperature, and depth) profiles taken during the respective research cruise (DY081; JC094; CINMS; NBP1103) or repeat seawater monitoring expeditions (Comau Fjord). These research cruise measurements are on average $30 \mathrm{~km}$ from coral sampling sites and typically within $30 \mathrm{~m}$ depth of the samples. Comau Fjord hydrographic data were considerably more proximal than this $(<5 \mathrm{~km}$ from coral sites and within $5 \mathrm{~m}$ depth). Where paired shipboard data were unavailable temperature estimates were taken from nearby sites in the GLODAP database (https://www.glodap.info/; Key et al., 2004). With the exception of the Galápagos site, these measurements were all within $280 \mathrm{~km}$ and $90 \mathrm{~m}$ water depth of coral sampling sites. First choice (most proximal) seawater bottle temperature estimates are typically within $0.3^{\circ} \mathrm{C}$ of GLODAP gridded temperature estimates (all within $1.9^{\circ} \mathrm{C}$; excluding Comau Fjord sites where GLODAP gridded data are unavailable). To further assess uncertainty on temperature estimates caused by natural variability and distance between coral and hydrographic stations, two additional nearby bottle seawater temperature measurements were selected from the compiled GLODAP and research cruise databases (Supplementary Information). For the majority of sites these temperatures 
were within $\pm 0.5^{\circ} \mathrm{C}(2 \sigma)$ of each other with a maximum variation of $\pm 3.3^{\circ} \mathrm{C}$ for one site in CINMS. In such cases where temperature was more variable, the most proximal bottle seawater temperature measurement is still preferred over averaging all three temperature estimates.

Surface water temperature measurements are typically subject to stronger seasonal bias than deep waters. Hence, annually averaged, $0.25^{\circ}$ gridded, World Ocean Atlas temperature data (years 1955 to 2012, Locarnini et al., 2013) were preferred for Caribbean CCA samples over temperature data taken at the time of collection because these are not representative of the annual average (Crook et al., 2012).

Similar to our compilation of sub-surface temperature, we estimate $\delta^{18} \mathrm{O}$ of seawater for each site using co-located measurements taken by remotely operated vehicle or CTD during the coral sampling expedition (JC094 and NBP1103); (Samperiz et al., 2020). Where such data are unavailable, $\delta^{18} \mathrm{O}$ of seawater was taken from nearby sites in the NASA Global Seawater Oxygen-18 Database (Schmidt et al., 1999). No nearby seawater $\delta^{18} \mathrm{O}$ data exist for Comau Fjord in any database, hence we assume values of mean ocean seawater $(0 \%)$ for these sites (Supplementary Information).

\subsection{Coral sample preparation}

Coral samples for this study were air dried following collection. The majority of organic matter was removed through physical scraping and treatment in dilute $\mathrm{NaClO}$ for $12 \mathrm{~h}$. Whole "S1" septa and attached theca were taken from cup corals (Balanophyllia, Caryophyllia, Desmophyllum, Flabellum, and Vaughanella) while whole calyxes were taken from branching Enallopsammia and Lophelia samples using a rotary cutting tool. Cross sectional discs ( $\sim 2 \mathrm{~mm}$ thickness) were cut from the central trunk (or widest branch) of stylasterid samples. The $\delta^{18} \mathrm{O}$ composition of growing tips of stylasterid branches has been shown to be further from seawater equilibrium than bulk samples (Samperiz et al., 2020), hence apical tips were avoided. Similarly, microstructures within deep-sea corals such as COCs are known to exhibit highly contrasting trace metal chemistry (Gagnon et al., 2007). Microsampling techniques (e.g. micromilling) can be time consuming and offer no guarantee that COCs are completely excluded, thus are often unfeasible when generating paleo-records (Stewart et al., 2016). As an alternative, sufficiently large samples were cut $(\sim 1 \mathrm{~g})$ that would diminish the influence of single microstructural components. While this sampling style may incorporate sample material grown across multiple decades, this approach is simple to follow and targets a representative average of bulk coral chemistry. To help confirm this, corals were sampled and analyzed in duplicate to characterise intra-sample variability. Initial results revealed greater trace metal variability for bulk-sampled Lophelia (whole calyxes) compared to other taxa (Section 3.2). For this reason, calyxes from 13 out of the 16 Lophelia specimens were resampled, however this time, septa were discarded by dentist drill leaving just the theca wall. In general, Lophelia theca walls contain proportionally fewer COCs than septa (Jurikova et al., 2019) and have been targeted in previous studies (e.g. Montagna et al., 2014) without the need for time consuming micromilling.

Coral and CCA fragments were finely crushed using a pestle and mortar before 5 to $10 \mathrm{mg}$ of the homogeneous powder was taken. While we were not sample limited in this instance, note that analysis could be performed on less than $1 \mathrm{mg}$ of powder if required. A warm $1 \% \mathrm{H}_{2} \mathrm{O}_{2}\left(80^{\circ} \mathrm{C}\right.$; buffered in $\left.\mathrm{NH}_{4} \mathrm{OH}\right)$ oxidative cleaning and weak acid polish $\left(0.0005 \mathrm{M} \mathrm{HNO}_{3}\right)$ were applied to the powders (Boyle, 1981; Rae et al., 2011) before dissolution in distilled $0.5 \mathrm{M} \mathrm{HNO}_{3}$.

\subsection{Analytical techniques}

Trace metal analyses were carried out at the University of Bristol using a Thermo Element2 ICP-MS, at the University of St Andrews using an Agilent 7500 ICP-MS, or at the National Institute of Standards and Technology (NIST; Hollings Marine Lab) using a Thermo ElementXR ICP-MS. An aliquot of the dissolved sample was analyzed using well-characterised, matrix-matched, synthetic standard solutions to yield $\mathrm{Li} / \mathrm{Ca}, \mathrm{Mg} / \mathrm{Ca}$, and $\mathrm{Sr} / \mathrm{Ca}$ ratios. The same primary calibrant (bracketing standard) was used at both University of Bristol and NIST. Repeat analysis of NIST RM 8301c $(n=35)$ and JCp-1 (uncleaned) carbonate reference materials yielded analytical precision of $< \pm 2 \%(1 \sigma)$ for these elemental ratios (Table 1 ).

Systematic analytical offsets between the labs were quantified and corrected using NIST RM 8301c results to bring values into line with interlaboratory comparison results reported in Hathorne et al. (2013b) and Stewart et al. (2015). To this end, $\mathrm{Li} / \mathrm{Ca}, \mathrm{Mg} / \mathrm{Ca}$ and $\mathrm{Sr} / \mathrm{Ca}$ ratios of samples measured at Bristol and NIST are corrected by a factor of $1.01,0.91$, and 0.97 respectively, while St Andrews values were corrected by a factor of $1.05,1.05$, and 1.06 respectively. A similar interlaboratory correction exercise was applied to published data according to reported JCp-1 results (Table 1; compiled data in Supplementary information).

Stable oxygen isotope analysis was performed at the National Environmental Isotope Facility based at the British Geological Survey. Approximately 60 to $100 \mu \mathrm{g}$ of carbonate powder were analysed using an IsoPrime dual inlet mass spectrometer plus Multiprep device. Samples were digested in anhydrous $\mathrm{H}_{3} \mathrm{PO}_{4}$ at $90^{\circ} \mathrm{C}$. The $\mathrm{CO}_{2}$ released was collected for 15 minutes, cryogenically cleaned and delivered to the mass spectrometer. $\delta^{18} \mathrm{O}$ is reported in per mil relative to VPDB using a within-run laboratory standard calibrated against NBS-19. A calcite-acid and aragonite-acid fractionation factor (1.00855), was applied to the respective gas-values along with the Craig correction factor to account for $\delta^{17} \mathrm{O}$. Average reproducibility of the standard calcite (KCM) was $0.05 \%$ for $\delta^{18} \mathrm{O}$. Note that Lophelia theca samples were not analysed for stable isotopic composition.

\section{Results and discussion}

\subsection{Stylasterid skeletal chemistry}

We compare trace metal values measured in bulk aragonitic scleractinia and high-Mg calcite CCA to our (i) solely aragonitic, (ii) both aragonitic and calcitic, and (iii) solely calcitic stylasterids (Fig. 4). Given the range of hydrographic conditions from which these sample sets were taken, we highlight the broadscale geochemical differences between the groups.

We find mineralogy to be a key factor controlling trace metal composition. Aragonitic stylasterids are low in both $\mathrm{Li} / \mathrm{Ca}$ $(\sim 12 \mu \mathrm{mol} / \mathrm{mol})$ and $\mathrm{Mg} / \mathrm{Ca}(\sim 2.9 \mathrm{mmol} / \mathrm{mol})$ and are therefore similar to their aragonitic counterparts, scleractinia (Fig. 4). However, stylasterids composed of high-Mg calcite have considerably higher $\mathrm{Li} / \mathrm{Ca}(\sim 55 \mu \mathrm{mol} / \mathrm{mol})$ and $\mathrm{Mg} / \mathrm{Ca}(\sim 82 \mathrm{mmol} / \mathrm{mol})$ ratios that are more similar to other high-Mg calcites such as CCA. Resultant $\mathrm{Li} / \mathrm{Mg}$ ratios of aragonitic and high-Mg calcite stylasterids are accordingly similar to scleractinia $(\sim 4.7 \mathrm{mmol} / \mathrm{mol})$ and CCA $(<1 \mathrm{mmol} / \mathrm{mol})$ respectively. Despite only representing a narrow temperature range $\left(0.1^{\circ} \mathrm{C}\right)$, we find that the stylasterid $E$. gracilis, that are composed of a mixture of aragonite and high-Mg calcite polymorphs, exhibit a wide range of $\mathrm{Li} / \mathrm{Mg}$ values $(0.9 \mathrm{mmol} / \mathrm{mol})$ that lie between these high aragonitic and low calcitic endmembers (Fig. 4).

Aragonitic stylasterids are only slightly higher in $\mathrm{Sr} / \mathrm{Ca}(\sim 11$ $\mathrm{mmol} / \mathrm{mol}$ ) compared to scleractinia, whereas these ratios are considerably lower in calcitic stylasterids $(\sim 2 \mathrm{mmol} / \mathrm{mol})$ and again 


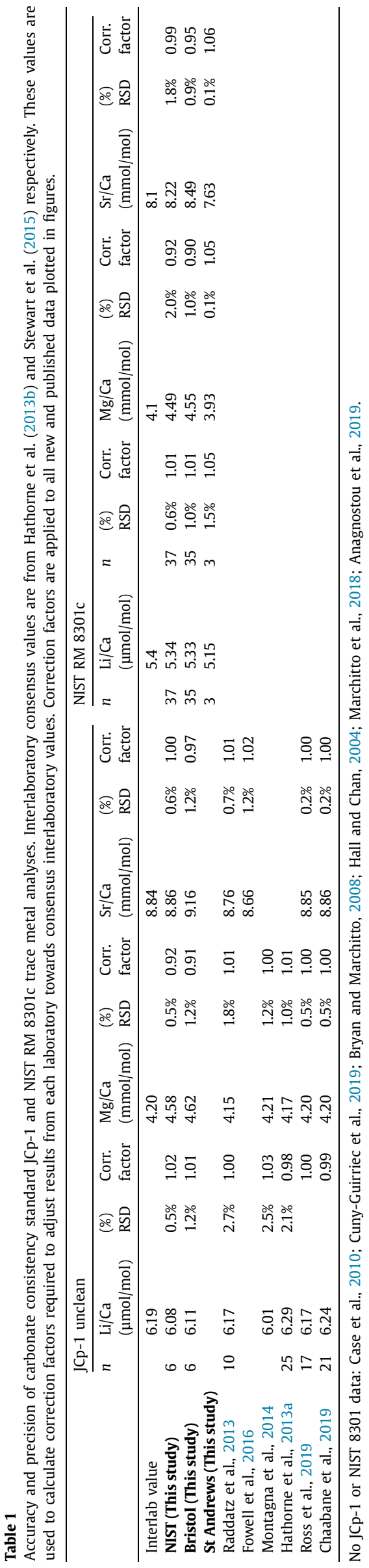

more similar to high-Mg calcitic CCA (Fig. 4). In general, therefore, trace metal compositions in aragonitic stylasterids and calcitic stylasterids are most similar to those of the organisms with similar mineralogy (i.e. scleractinia and CCA respectively), with elemental chemistry of mixed-mineralogy stylasterids falling on a mixing line between these two endmembers.

When our scleractinian coral stable isotope data are compared to that of stylasterids (Samperiz et al., 2020), the mineralogical dependency is less clear. Aragonitic stylasterid $\delta^{18} \mathrm{O}$ and $\delta^{13} \mathrm{C}$ values are slightly higher, but considerably less variable than aragonitic scleractinia. Furthermore, average high-Mg calcite stylasterid $\delta^{18} \mathrm{O}$ is largely indistinguishable from aragonitic Stylasteridae or Scleractinia (Fig. 4).

\subsection{Trace metal and stable isotope heterogeneity of corals}

It is important to consider the impact of non-uniform internal skeletal chemistry on coral temperature proxies. In all but three specimens, two solid pieces of each coral were analysed. We assess the chemical heterogeneity within each coral specimen by calculating the difference between replicate $\delta^{18} \mathrm{O}, \mathrm{Sr} / \mathrm{Ca}$, and $\mathrm{Li} / \mathrm{Mg}$ analyses. In Table 2 we report the median of these differences for each coral taxonomic group.

The mixed-mineralogy stylasterid species E. gracilis $(n=4)$ showed large median difference for both $\mathrm{Li} / \mathrm{Mg}$ and $\mathrm{Sr} / \mathrm{Ca}$ replicates ( 0.5 and $0.4 \mathrm{mmol} / \mathrm{mol}$ respectively). This result is unsurprising given the mixture of aragonitic and calcitic polymorphs that makes up the skeleton of this species. This large range in trace metal composition between replicates is in contrast to the pure high$\mathrm{Mg}$ calcite (E. laterorifa; $n=2$ ) and pure aragonite (E. antarctica, E. boschmai, E. altispina, Stylaster) stylasterids that have median differences of $<0.1 \mathrm{mmol} / \mathrm{mol}$ for both of these elemental ratios (i.e. within analytical uncertainty).

The majority of aragonitic scleractinian genera we measured also replicate well (median $\mathrm{Sr} / \mathrm{Ca}$ and $\mathrm{Li} / \mathrm{Mg}$ differences of $<0.3$ and $<0.12 \mathrm{mmol} / \mathrm{mol}$ respectively; Table 2). This small intraspecimen range in $\mathrm{Li} / \mathrm{Mg}$ would result in a reconstructed temperature range of less than $0.6^{\circ} \mathrm{C}$. However, we find $\mathrm{Li} / \mathrm{Mg}$ replicates of Balanophyllia and Lophelia vary by more than $0.2 \mathrm{mmol} / \mathrm{mol}$ resulting in estimated temperature discrepancies of $>1{ }^{\circ} \mathrm{C}$. We are unable to assess the significance of poor replication in Balanophyllia with the limited number of specimens available. However, multiple Lophelia specimens replicated poorly for both trace metal compositions and $\delta^{18} \mathrm{O}(>0.4 \%$ ), with $\mathrm{Li} / \mathrm{Mg}$ replicates in one specimen varying by $4.34 \mathrm{mmol} / \mathrm{mol}$ (CINMSLoph-004, replicate $1 \mathrm{Li} / \mathrm{Mg}=$ $7.17 \mathrm{mmol} / \mathrm{mol}$, i.e. higher than all other $\mathrm{Li} / \mathrm{Mg}$ measurements). While outliers can occur for analytical reasons (particularly for the more challenging Li measurement), numerous studies have suggested that Lophelia are particularly chemically heterogeneous between micro-structures (Jurikova et al., 2019; Montagna et al., 2014; Raddatz et al., 2013). Our results therefore suggest that chemically heterogeneous taxa such as Lophelia should be treated with caution when sampled in bulk for paleo-temperature proxy reconstruction (discussed further in Section 3.3.1).

Scleractinian coral $\delta^{13} \mathrm{C}$ and $\delta^{18} \mathrm{O}$ have been observed to positively covary, due to a combination of kinetic isotope effects (McConnaughey, 1989), pH dependent dissolved inorganic carbon speciation (Adkins et al., 2003), and carbonic anhydrase activity (Chen et al., 2018), which can shift coral stable isotope ratios towards values lower than those expected from seawater equilibrium. Biocalcification models suggest that carbon enters the coral ECF via a seawater leak $\left(\delta^{13} \mathrm{C} \sim+1 \%\right.$ ) and from cell-derived $\mathrm{CO}_{2}\left(\delta^{13} \mathrm{C}\right.$ $\sim-8 \%$ ). However, the broadly linear $\delta^{18} \mathrm{O}$ vs $\delta^{13} \mathrm{C}$ relationship is predicted to plateau at a $\delta^{13} \mathrm{C}$ value of approximately $-8 \%$, at the point where all of the carbon in the ECF is cell derived (Fig. 5A; 

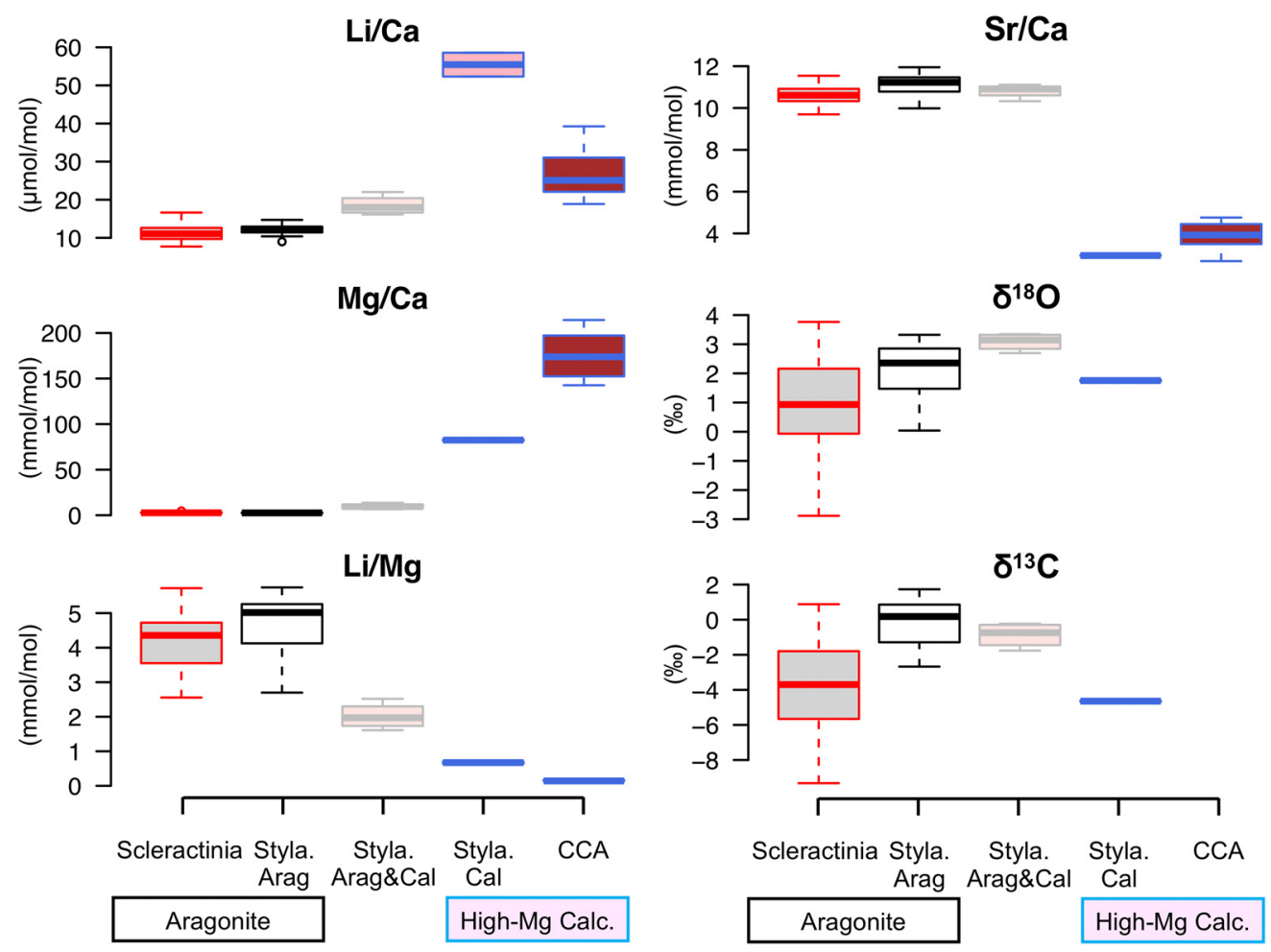

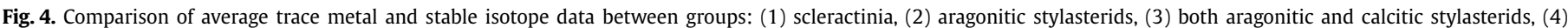

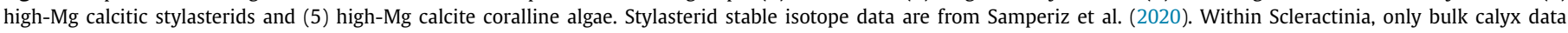
are included for Lophelia samples.

Table 2

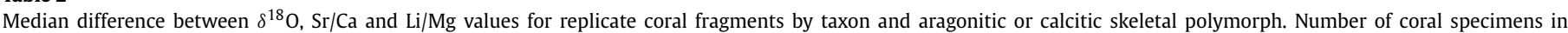

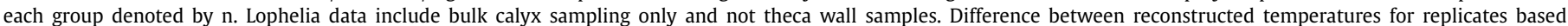

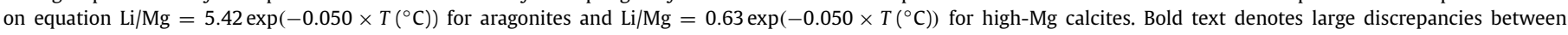
replicates discussed in the main text.

\begin{tabular}{|c|c|c|c|c|c|c|c|}
\hline Taxa & & $n$ & Polymorph & $\begin{array}{l}\text { Median diff. between } \\
\delta^{18} 0 \text { reps } \\
(\% 0)\end{array}$ & $\begin{array}{l}\text { Median diff. between } \\
\mathrm{Sr} / \mathrm{Ca} \text { reps } \\
(\mathrm{mmol} / \mathrm{mol})\end{array}$ & $\begin{array}{l}\text { Median diff. between } \\
\mathrm{Li} / \mathrm{Mg} \text { reps } \\
(\mathrm{mmol} / \mathrm{mol})\end{array}$ & $\begin{array}{l}\mathrm{Li} / \mathrm{Mg} \text { temperature } \\
\text { difference } \\
\left({ }^{\circ} \mathrm{C}\right)\end{array}$ \\
\hline Scleractinia & Balanophyllia & 2 & Aragonite & 0.14 & 0.03 & 0.26 & 1.4 \\
\hline Scleractinia & Caryophylliidae & 22 & Aragonite & 0.24 & 0.27 & 0.07 & 0.3 \\
\hline Scleractinia & Desmophyllum & 17 & Aragonite & 0.39 & 0.20 & 0.09 & 0.5 \\
\hline Scleractinia & Enallopsammia & 8 & Aragonite & 0.42 & 0.29 & 0.12 & 0.6 \\
\hline Scleractinia & Flabellum & 15 & Aragonite & 0.18 & 0.13 & 0.09 & 0.4 \\
\hline Scleractinia & Lophelia & 16 & Aragonite & 0.45 & 0.47 & 0.21 & 1.2 \\
\hline Stylasterids & $\begin{array}{l}\text { E. antarctica } \\
\text { E. boschmai } \\
\text { E. altispina } \\
\text { Stylaster }\end{array}$ & 16 & Aragonite & 0.14 & 0.20 & 0.09 & 0.4 \\
\hline Stylasterids & E. gracilis & 4 & Arag./Calc. & 0.13 & 0.39 & 0.54 & $\mathrm{~N} / \mathrm{A}$ \\
\hline Stylasterids & E. laterorifa & 2 & High-Mg calcite & 0.27 & 0.02 & 0.03 & 0.8 \\
\hline
\end{tabular}

(Chen et al., 2018). These extremely light stable isotope signatures are typical of rapidly accreting coral COCs (Chen et al., 2018).

Our bulk scleractinian coral data fit the predicted general linear trend between $\delta^{18} \mathrm{O}$ and $\delta^{13} \mathrm{C}$ (Chen et al., 2018), with results significantly lower than equilibrium values for the vast majority of specimens (Fig. 5A; average $\delta^{13} \mathrm{C}=-3.8 \%$; $\delta^{18} \mathrm{O}=+1.0 \%$ ). This result is consistent with strong modification of carbonate chemistry within the ECF of scleractinian corals. Bulk calyx Lophelia $\delta^{13} \mathrm{C}$ in particular is at the low end of the range in stable isotope values (average $\delta^{13} \mathrm{C}=-6.5 \%$ ), with many replicates close to the predicted minimum $\delta^{13} \mathrm{C}$ value of $-8 \%$. This suggests that close to $100 \%$ of the carbon in these specimens is cell derived. This result contrasts with steady-state geochemical modelling (DeCarlo et al., 2015) and isotope labelling experiments (Furla et al., 2000) that suggest typically only $75 \%$ of precipitated carbon in other scleractinian groups is biologically sourced. These Lophelia samples with extremely low $\delta^{13} \mathrm{C}$ values also have particularly high $\mathrm{Mg} / \mathrm{Ca}$ ratios (Fig. $5 \mathrm{~B} ;>3 \mathrm{mmol} / \mathrm{mol}$ ). Together, these results suggest that bulk calyx Lophelia incorporate material precipitated from an ECF that is more restricted from seawater resulting microstructural chemistry that is variable and highly modified from equilibrium. This is in stark contrast to $\delta^{18} \mathrm{O}$ and $\delta^{13} \mathrm{C}$ values in aragonitic Stylasterid corals, which occupy a narrow range (Fig. 4) and are generally higher than those of Scleractinia, thus plotting closer to seawater equilibrium (Fig. 5A; Samperiz et al., 2020).

\subsection{Temperature proxies}

3.3.1. $\delta^{18} \mathrm{O}, \mathrm{Sr} / \mathrm{Ca}$ and $\mathrm{Li} / \mathrm{Mg}$ in scleractinia and aragonitic stylasterids

In light of disparity between replicate samples of Lophelia we first compare results from bulk calyxes to theca-only sub-samples in this genus. We illustrate this by plotting Lophelia $\mathrm{Li} / \mathrm{Ca}, \mathrm{Mg} / \mathrm{Ca}$, 

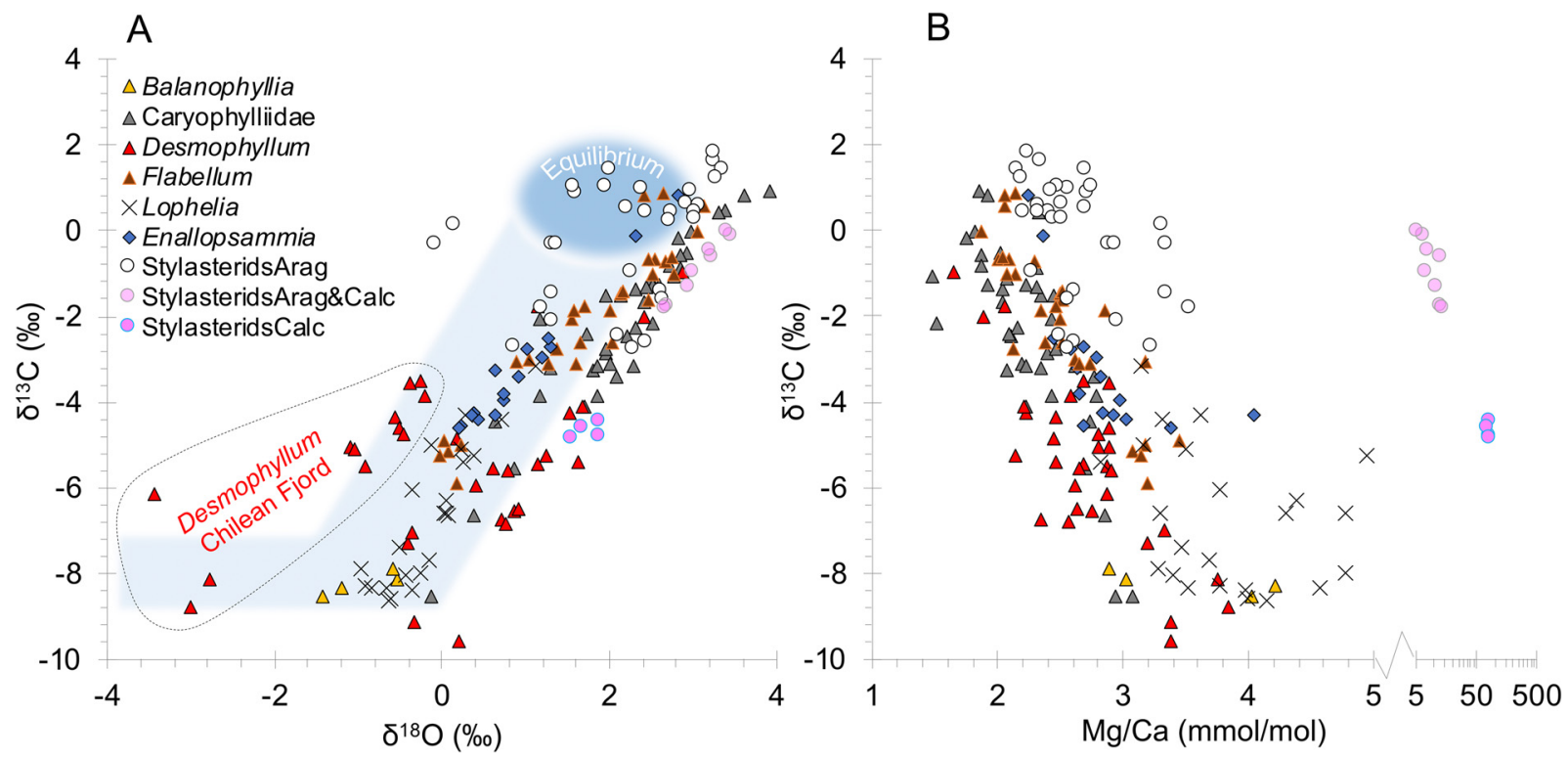

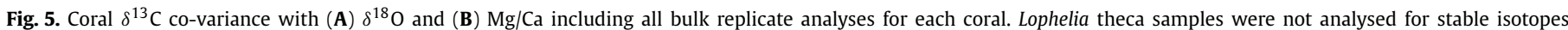

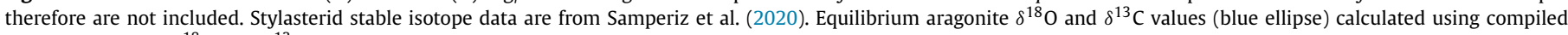

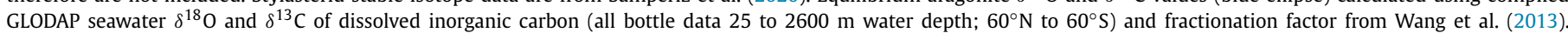

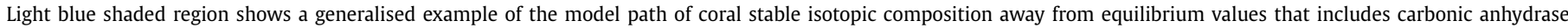

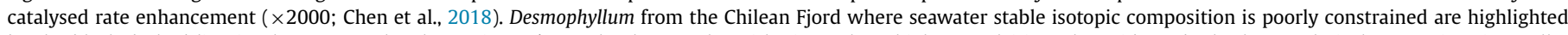

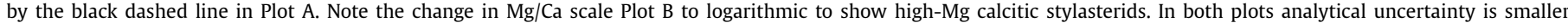
than the marker size.

$\mathrm{Sr} / \mathrm{Ca}$, and $\mathrm{Li} / \mathrm{Mg}$ results against seawater temperature in Fig. 6 . The narrow seawater temperature range of these regression equations mean that they are of little use for paleo-proxy studies. However, the absolute values, range of trace metal results, and $R^{2}$ values of the regressions give a sense of microstructural bias and the broader temperature-proxy-suitability of these sampling approaches for Lophelia. Bulk calyx replicates are on average 8 and 9\% more enriched in $\mathrm{Li}$ and $\mathrm{Mg}$ respectively than theca-only samples from the same specimens (Fig. 6A and B). Despite averaging two bulk calyx replicates, the range in both $\mathrm{Sr} / \mathrm{Ca}$ and $\mathrm{Li} / \mathrm{Mg}$ results is still larger (>30\%) than theca sampling alone (Fig. 6C and D). While $\mathrm{Sr} / \mathrm{Ca}$ results for both sampling approaches show little coherency with seawater temperature $\left(R^{2}<0.22\right)$, Li/Mg measured in Lophelia specimens sampled for just theca wall material yields a tighter relationship with temperature $\left(R^{2}>0.7\right)$ than bulk calyx sampling. Even if the one anomalous bulk calyx $\mathrm{Li} / \mathrm{Mg}$ value for sample CINMSLoph-004 is removed, the $R^{2}$ value of the bulk calyx exponential relationship remains less than 0.5. Taken together with $\delta^{13} \mathrm{C}$ and $\mathrm{Mg} / \mathrm{Ca}$ results (Fig. 5B), we infer that high $\mathrm{Li}$ and $\mathrm{Mg}$ content and inconsistent $\mathrm{Li} / \mathrm{Mg}$ ratios in bulk Lophelia are being driven, at least in part, by the incorporation of greater amounts of skeletal COCs in the septa, precipitated from a highly restricted ECF. Despite Li/Mg being considered minimally impacted by calcification processes ( $c f$. $\mathrm{Li} / \mathrm{Ca}$ and $\mathrm{Mg} / \mathrm{Ca}$ ), this interpretation is consistent with modelling results that suggest more extreme closedsystem calcification does begin to modify skeletal Li/Mg (Marchitto et al., 2018). For this reason, we recommend that future paleotemperature studies use Lophelia sample theca walls and avoid the inclusion of septa. Accordingly, for all temperature regression analysis using trace metal data in subsequent discussion (Fig. 7; Fig. 1B) we use theca samples for Lophelia specimens where available.

We assess the individual temperature dependency of each of our cold-water coral $\delta^{18} \mathrm{O}, \mathrm{Sr} / \mathrm{Ca}$ and $\mathrm{Li} / \mathrm{Mg}$ proxy datasets (Fig. 7). In line with previous findings, we show that scleractinian coral $\delta^{18} \mathrm{O}$ is poorly correlated with seawater temperature $\left(R^{2}=0.34\right.$; Fig. 7A), with little coherent relationship even if samples are sep- arated at the genus level. Adjustment of these coral $\delta^{18} \mathrm{O}$ values for differences in $\delta^{18} \mathrm{O}$ of seawater at each site (i.e. $\delta^{18} \mathrm{O}_{\text {coral }}$ - $\left.\delta^{18} \mathrm{O}_{\text {seawater }}\right)$ yields no better correlation with temperature $\left(R^{2}\right.$ value reduces to 0.22 ) and is likely hindered by poorly constrained seawater values in the Chilean Fjord sites (Fig. 5A). Nevertheless, our result is consistent with the overwhelming influence of ion pumping and growth rate effects on scleractinian $\delta^{18} \mathrm{O}$ (Chen et al., 2018). Aragonitic stylasterids by contrast show generally higher $\delta^{18} \mathrm{O}$ values, with a stronger correlation with temperature $(T)$ (Samperiz et al., 2020), described by the equation,

$$
\begin{aligned}
& \delta^{18} \mathrm{O}_{\text {Stylasterid(Arag) }}=-0.20[ \pm 0.02] \times T\left({ }^{\circ} \mathrm{C}\right)+3.02[ \pm 0.14] \\
& \left(R^{2}=0.84\right)
\end{aligned}
$$

This is consistent with the inference from paired $\delta^{18} \mathrm{O}$ and $\delta^{13} \mathrm{C}$ above that stylasterid species precipitate close to seawater equilibrium. For direct comparison to trace metal temperature proxy results, in Equation (2) and Fig. 7A we show only the $\delta^{18} \mathrm{O}$ values for aragonitic stylasterid specimens used in this study and exclude data from other genera measured by Samperiz et al. (2020). These stylasterid $\delta^{18} \mathrm{O}$ are also unadjusted for $\delta^{18} \mathrm{O}$ of seawater since it is a value that is poorly constrained for paleo-temperature reconstructions. Nevertheless, the relationship we show in Equation (2) is similar to the full compiled aragonitic stylasterid $\delta^{18} \mathrm{O}$ temperature calibration published by Samperiz et al. (2020):

$$
\begin{aligned}
& \delta^{18} \mathrm{O}_{\text {Stylasterid }(\text { Arag })}=-0.22[ \pm 0.01] \times T\left({ }^{\circ} \mathrm{C}\right)+3.33[ \pm 0.06] \\
& \left(R^{2}=0.91\right)
\end{aligned}
$$

Cold-water coral $\mathrm{Sr} / \mathrm{Ca}$ values have a similar pattern to the $\delta^{18} \mathrm{O}$ data when comparing Scleractinia with aragonitic stylasterids (Fig. 7B). Scleractinian $\mathrm{Sr} / \mathrm{Ca}$ is poorly correlated with seawater temperature $\left(R^{2}=0.29\right)$; a result that is again consistent with a dominant growth-rate effect in this group (Gagnon et al., 2007). However, aragonitic stylasterid $\mathrm{Sr} / \mathrm{Ca}$ correlates with seawater temperature according to the equation, 


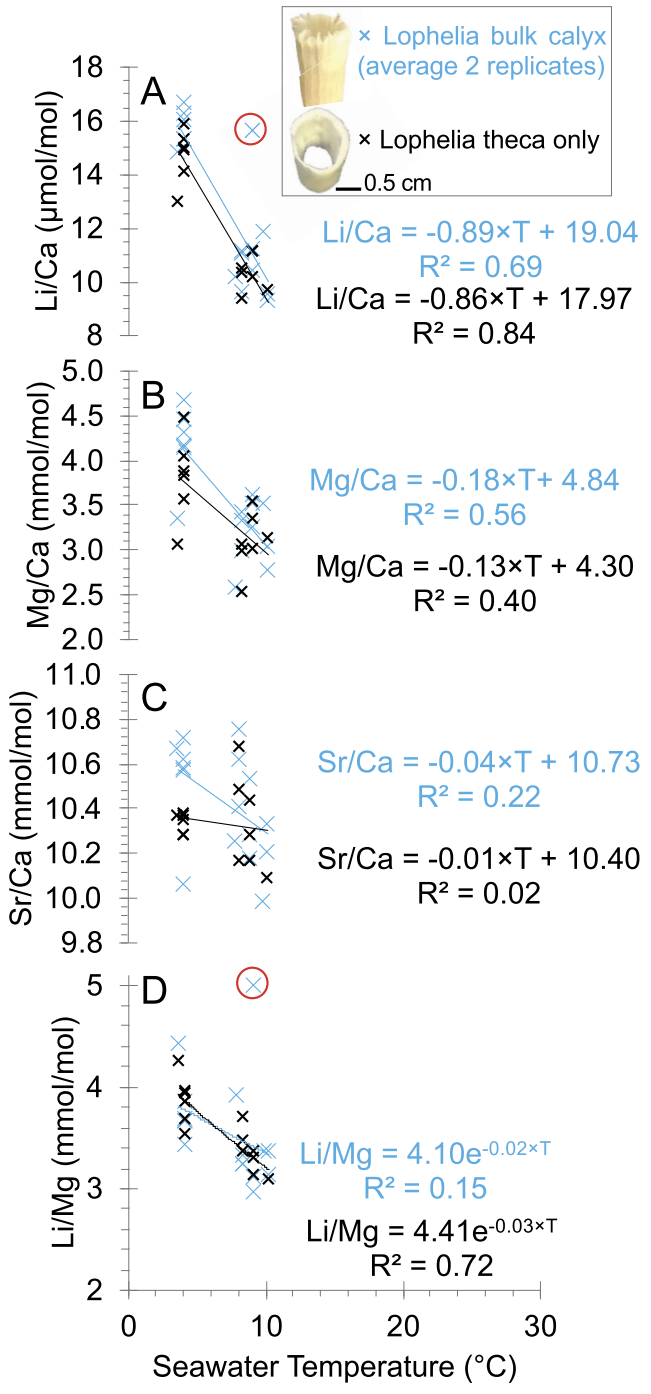

Fig. 6. Impact of sampling technique on Lophelia $\mathrm{Li} / \mathrm{Ca}, \mathrm{Mg} / \mathrm{Ca}, \mathrm{Sr} / \mathrm{Ca}$, and $\mathrm{Li} / \mathrm{Mg}$ ratios plotted against temperature. We compare the average of two bulk calyx replicates and theca only samples (presumed lower COC content). The Li measurement discussed in the main text as potentially anomalous is highlighted by a red circle. Analytical uncertainty is smaller than the marker size.

$\mathrm{Sr} / \mathrm{Ca}_{\text {Stylasterid }(\mathrm{Arag})}=-0.11[ \pm 0.02] \times T\left({ }^{\circ} \mathrm{C}\right)+11.61[ \pm 0.09]$ $\left(R^{2}=0.79\right)$

$\mathrm{Li} / \mathrm{Ca}$ and $\mathrm{Mg} / \mathrm{Ca}$ results show respectively weak negative and weak positive relationships with temperature for scleractinia, aragonitic stylasterids, and also high-Mg calcite (Stylasterids and CCA) groups (Fig. 7C and D). While correlations are too weak to determine if these relationships are exponential (e.g. Montagna et al., 2014), $\mathrm{Li} / \mathrm{Ca}$ and $\mathrm{Mg} / \mathrm{Ca}$ ratios both change on the order of $2.5 \%$ per ${ }^{\circ} \mathrm{C}$ for both aragonitic and high-Mg calcites. Similar to $\delta^{18} \mathrm{O}$ and $\mathrm{Sr} / \mathrm{Ca}$ results, we find aragonitic stylasterid $\mathrm{Li} / \mathrm{Ca}$ and $\mathrm{Mg} / \mathrm{Ca}$ ratios to have slightly stronger correlations with temperature than scleractinia, however $R^{2}$ values remain lower than 0.63 .

By contrast, $\mathrm{Li} / \mathrm{Mg}$ ratios show by far the most coherent relationships with temperature across the coral groups in this study (Fig. 7E). Consistent with previous studies (Case et al., 2010; Montagna et al., 2014) scleractinian coral Li/Mg data are well correlated with seawater temperature, fitting an exponential relationship,

$\mathrm{Li} / \mathrm{Mg}_{\text {Scleractinia }}=5.57[ \pm 0.12] \mathrm{e}^{-0.053[ \pm 0.003] \times T\left({ }^{\circ} \mathrm{C}\right)}$

$\left(R^{2}=0.77\right)$
Aragonitic stylasterid corals fit a similar, exponential relationship, that explains considerably more of the variance (95\%) and with less overall scatter,

$$
\begin{aligned}
& \mathrm{Li} / \mathrm{Mg}_{\text {Stylasterid(Arag) }}=5.64[ \pm 0.09] \mathrm{e}^{-0.046[ \pm 0.003] \times T\left({ }^{\circ} \mathrm{C}\right)} \\
& \left(R^{2}=0.95\right)
\end{aligned}
$$

Regression analyses such as these are open to bias by a small number of data points if the ambient seawater temperatures for the sample set are unevenly distributed. The aragonitic stylasterid calibrations might therefore be strongly weighted by the one specimen collected from warmer waters $\left(\sim 16^{\circ} \mathrm{C}\right)$. In this case however, exclusion of this sample has little impact on slope and intercept of the regressions outlined above (Aragonitic stylasterids $<10^{\circ} \mathrm{C}$ : $\left.\mathrm{Li} / \mathrm{Mg}=5.67 \mathrm{e}^{-0.047} \times T\left({ }^{\circ} \mathrm{C}\right) ; R^{2}=0.90\right)$

These results open the possibility of $\delta^{18} \mathrm{O}, \mathrm{Sr} / \mathrm{Ca}$ and $\mathrm{Li} / \mathrm{Mg}$ based temperature proxy reconstructions using aragonitic stylasterids. However, the strong geochemical dependence on mineralogy requires that sample mineralogy must be known so that specimens containing a mixture of aragonitic and high-Mg calcite are avoided (Fig. 4; Fig. 7B and E).

Through combining our scleractinia and aragonitic stylasterid results with published $\mathrm{Li} / \mathrm{Mg}$ measurements in biogenic aragonites (including foraminifera and zooxanthellate corals) we find the following relationship with temperature for all aragonitic corals and foraminifera across the range 0 to $30^{\circ} \mathrm{C}$ (Fig. 1B),

$$
\begin{aligned}
& \mathrm{Li} / \mathrm{Mg}_{\text {All aragonite }}=5.42[ \pm 0.04] \mathrm{e}^{-0.050[ \pm 0.0004] \times T\left({ }^{\circ} \mathrm{C}\right)} \\
& \left(R^{2}=0.97\right)
\end{aligned}
$$

This refined calibration is within uncertainty of the original exponential fit by Montagna et al. (2014), however, the addition of these new cold-water coral specimens means that we can now explain more of the variance in $\mathrm{Li} / \mathrm{Mg}$. We also greatly expand the calibration dataset that was previously dominated by shallowwater zooxanthellate corals. The inclusion of aragonitic stylasterids in this calibration further supports that this relationship to temperature is universal to all biogenic aragonites and $\mathrm{Li} / \mathrm{Mg}$ is minimally impacted by growth rates and organism specific vital effects. This same calibration can therefore be used to generate paleotemperature records from aragonitic foraminifera collected from deep-sea sediment cores (e.g. Marchitto et al., 2018), individual coral cores (e.g. Fowell et al., 2016), and radiometrically dated solitary cold-water coral samples of any species (e.g. Case et al., 2010).

\subsection{2. $\mathrm{Li} / \mathrm{Mg}$ in high-Mg calcite stylasterids}

E. gracilis samples (both aragonitic and calcitic) from this sample set vary along a clear mixing line between high $\mathrm{Li} / \mathrm{Mg}$ values in solely aragonitic stylasterids and low Li/Mg values in solely calcitic. Until further data are generated for this group and other mixed mineralogy carbonates (e.g. Molluscs; Dellinger et al., 2018) across a wide range of hydrographic conditions, we must assume that mixed aragonitic and calcitic stylasterids have little apparent paleo-temperature proxy potential and we exclude them from further discussion.

There have been few studies exploring the Li/Mg temperature relationship in biogenic high-Mg calcites. However, $\mathrm{Li} / \mathrm{Mg}$ data measured in CCA specimens grown in culture, across a $7^{\circ} \mathrm{C}$ temperature range, suggest a linear relationship (Fig. 1A; Table 3; Anagnostou et al., 2019). The nature of a Li/Mg-temperature relationship in high-Mg calcite organisms is questioned however by calcitic coral data from across a $3.5^{\circ} \mathrm{C}$ temperature range that show little temperature sensitivity (Fig. 1A; Chaabane et al., 2019). Yet, over a narrow temperature ranges such as these, it remains impossible to ascertain if the relationship is in fact exponential as it is in aragonitic organisms, and further data are required. 

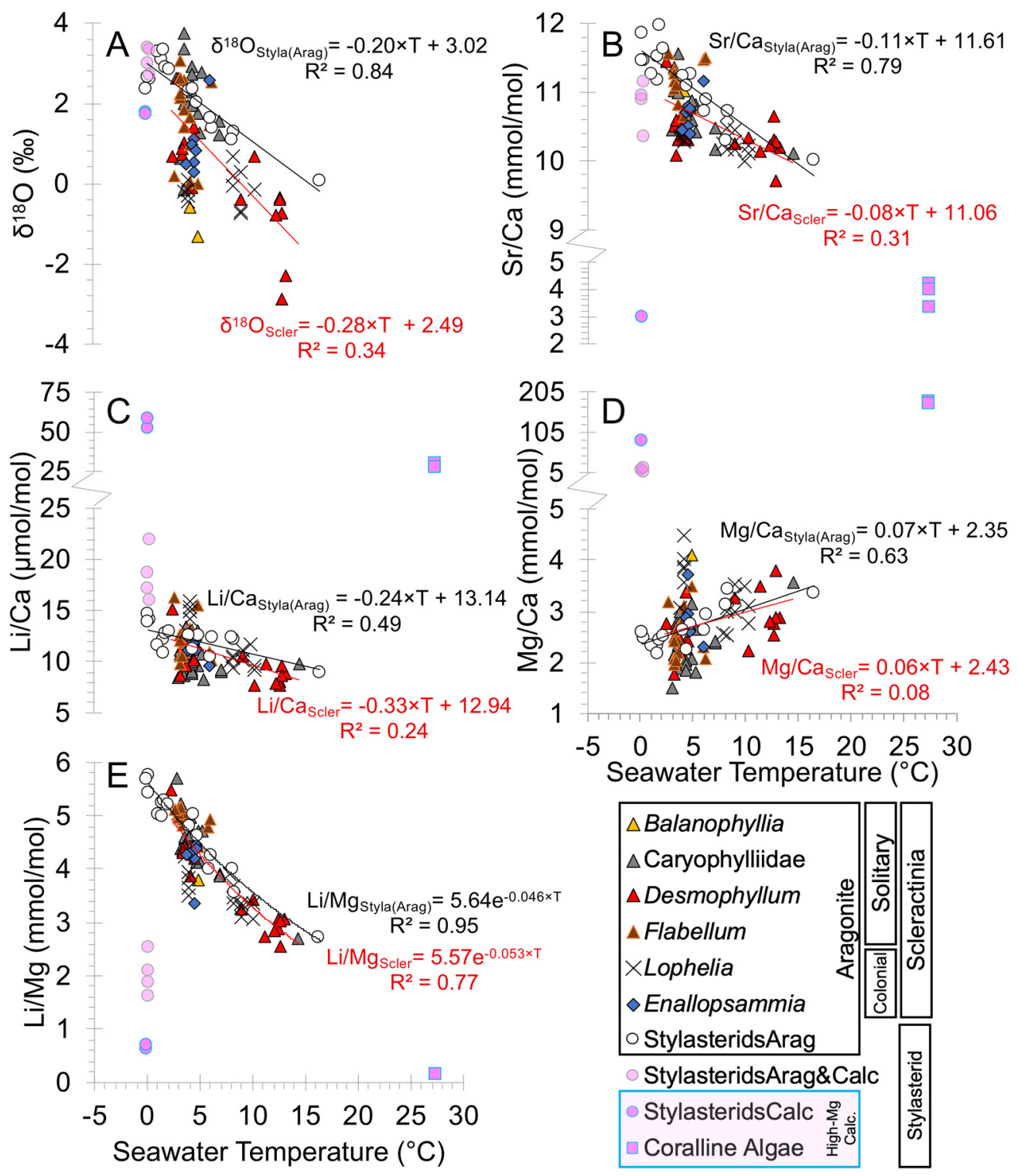

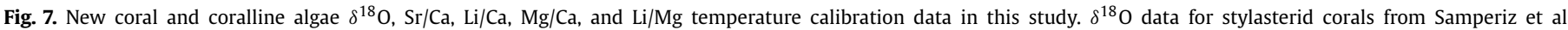

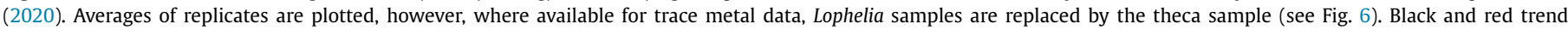
lines are for respectively aragonitic stylasterids and scleractinia data. In all plots analytical uncertainty is smaller than the marker size.

Table 3

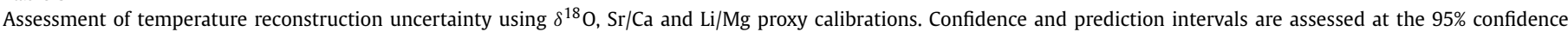

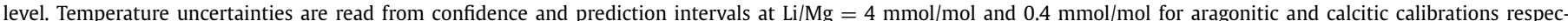

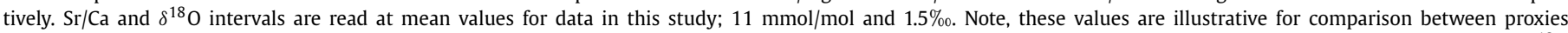

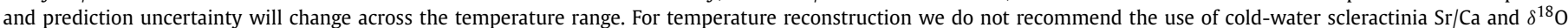
calibrations (greyed out) owing to their large prediction intervals $\left(> \pm 6^{\circ} \mathrm{C}\right)$.

\begin{tabular}{|c|c|c|c|c|c|}
\hline \multicolumn{4}{|c|}{ Calibration } & \multirow{2}{*}{$\begin{array}{l}\text { Confidence interval } \\
\text { temperature uncert. } \\
\left( \pm{ }^{\circ} \mathrm{C}\right) \\
0.35\end{array}$} & \multirow{2}{*}{$\begin{array}{l}\text { Prediction interval } \\
\text { temperature uncert. } \\
\left( \pm{ }^{\circ} \mathrm{C}\right) \\
3.5\end{array}$} \\
\hline $\mathrm{Li} / \mathrm{Mg}$ & All published aragonites & $\mathrm{Li} / \mathrm{Mg}=5.27 \exp (-0.049 \times T)$ & (Equation (1)) & & \\
\hline $\mathrm{Li} / \mathrm{Mg}$ & All aragonites (new calibration) & $\mathrm{Li} / \mathrm{Mg}=5.42 \exp (-0.050 \times T)$ & (Equation (7)) & 0.25 & 3.4 \\
\hline $\mathrm{Li} / \mathrm{Mg}$ & Aragonitic stylasterids (this study) & $\mathrm{Li} / \mathrm{Mg}=5.64 \exp (-0.046 \times T)$ & (Equation (6)) & 0.65 & 2.3 \\
\hline $\mathrm{Sr} / \mathrm{Ca}$ & Aragonitic stylasterids (this study) & $\mathrm{Sr} / \mathrm{Ca}=-0.11 \times T+11.61$ & (Equation (4)) & 1.33 & 5.3 \\
\hline $\mathrm{Sr} / \mathrm{Ca}$ & Scleractinia (this study) & $\mathrm{Sr} / \mathrm{Ca}=-0.08 \times T+11.06$ & & 2.16 & $>7.7$ \\
\hline$\delta^{18} \mathrm{O}$ & Aragonitic stylasterids (samples in this study) & $\delta^{18} \mathrm{O}=-0.20 \times T+3.02$ & (Equation (2)) & 1.45 & 4.5 \\
\hline$\delta^{18} \mathrm{O}$ & Aragonitic stylasterids (Samperiz et al., 2020) & $\delta^{18} \mathrm{O}=-0.22 \times T+3.33$ & (Equation (3)) & & 3.5 \\
\hline$\delta^{18} \mathrm{O}$ & Scleractinia (this study) & $\delta^{18} \mathrm{O}=-0.28 \times T+2.49$ & & 1.16 & 8.5 \\
\hline $\mathrm{Li} / \mathrm{Mg}$ & Coralline Algae (linear fit; Anagnostou et al., 2019) & $\mathrm{Li} / \mathrm{Mg}=-0.02 \times T+0.57$ & & 0.51 & 3.0 \\
\hline $\mathrm{Li} / \mathrm{Mg}$ & All high-Mg calcites (new calibration) & $\mathrm{Li} / \mathrm{Mg}=0.63 \exp (-0.050 \times T)$ & (Equation (8)) & 0.51 & 3.4 \\
\hline
\end{tabular}


When the Li/Mg results of high-Mg calcite stylasterids are combined with our data from shallow-water CCA collected from the Caribbean, published values from Anagnostou et al. (2019), as well as Corallium rubrum data from Chaabane et al. (2019), we find the following exponential relationship for high-Mg calcite organisms (Fig. 1B),

$\mathrm{Li} / \mathrm{Mg}_{\text {All high-Mg calcite }}=0.63[ \pm 0.02] \mathrm{e}^{-0.050[ \pm 0.002] \times T\left({ }^{\circ} \mathrm{C}\right)}$

$\left(R^{2}=0.92\right)$

While the higher $\mathrm{Mg}$ content of these organisms determines that the intercept of this trendline is lower compared to biogenic aragonites, we find that the exponent of Equation (7) and Equation (8) is remarkably similar. This encouraging result invites further study to characterise the $\mathrm{Li} / \mathrm{Mg}$ relationship to temperature in multiple high-Mg calcitic organisms to fully assess their paleooceanographic utility.

\subsection{Biological controls on trace metal incorporation}

Our compiled data show that $\mathrm{Li} / \mathrm{Mg}$ ratios in both biogenic aragonite and high-Mg calcites decrease by $5 \%$ per ${ }^{\circ} \mathrm{C}$ change in seawater temperature. Given the phylogenetic separation of groups within each temperature calibration as high as Kingdom level (Fig. 2), this result strongly suggests an abiogenic incorporation mechanism exists for these elements. While $D_{\mathrm{Li}}$ and $D_{\mathrm{Mg}}$ differ greatly between aragonites and high-Mg calcites in absolute terms, $\mathrm{Li} / \mathrm{Ca}$ and $\mathrm{Mg} / \mathrm{Ca}$ values in this study respectively increase and decrease on the order of $2.5 \%$ per ${ }^{\circ} \mathrm{C}$ in both of these types of carbonate (Fig. 7C and D). It is likely therefore that similarity between exponents of $\mathrm{Li} / \mathrm{Mg}$ temperature relationships in our aragonite and high-Mg calcite samples is driven by a largely equal abiogenic temperature dependency on both partition coefficients. Further study into the controls on $\mathrm{Li} / \mathrm{Mg}$ ratios in low- $\mathrm{Mg}$ calcites is required to ascertain if this temperature sensitivity is universal to all calcium carbonates.

While we find temperature to be an important factor driving both $\mathrm{Sr} / \mathrm{Ca}$ and $\mathrm{Li} / \mathrm{Mg}$ in scleractinian and stylasterid corals, the secondary biological controls on incorporation of these elements have long been debated (Marchitto et al., 2018; Montagna et al., 2014). We find that the residuals for the $\mathrm{Sr} / \mathrm{Ca}$ and $\mathrm{Li} / \mathrm{Mg}$ relationships with temperature (Fig. 7B and Fig. 7E) are positively correlated for scleractinian corals according to the equation:

$\mathrm{Sr} /$ Ca residuals $=0.55 \times \mathrm{Li} / \mathrm{Mg}$ residuals $+0.01 \quad\left(R^{2}=0.35\right)(9)$

Although correlation is weak, this relationship is similar to that reported for scleractinian corals by Ross et al. (2019). Yet, we find no such correlation $\left(R^{2}=0.01\right)$ for the residuals for aragonitic stylasterid coral temperature relationships:

$\mathrm{Sr} /$ Ca residuals $=0.10 \times \mathrm{Li} / \mathrm{Mg}$ residuals +0.01

$\left(R^{2}=0.01\right)$

$\mathrm{Li} / \mathrm{Mg}$ is thought to be unaffected by [Ca] of the ECF, however, biogenic carbonate precipitation experiments suggest that the partition coefficient of $\mathrm{Li} / \mathrm{Mg}$ is sensitive to carbonate ion concentration (Holcomb et al., 2016; Ross et al., 2019). Sr/Ca may also be indirectly influenced by $\left[\mathrm{CO}_{3}^{2-}\right]$ in the ECF if kinetic effects and/or Rayleigh fractionation become more dominant as $\left[\mathrm{CO}_{3}^{2-}\right]$ increases (Ross et al., 2019). The absence of correlation between residuals in aragonitic stylasterid corals that calcify close to equilibrium with seawater suggests that modification of ECF carbonate chemistry exerts a secondary control on both $\mathrm{Sr} / \mathrm{Ca}$ and $\mathrm{Li} / \mathrm{Mg}$ ratios in scleractinian corals.

\subsection{Temperature prediction uncertainty}

When interpreting any paleoceanographic record it is important to consider the fidelity with which a proxy is able reproduce the hydrographic parameter of choice. To this end, it has become the convention in many proxy calibration studies to quote confidence intervals on the regression (e.g. Anand et al., 2003). This approach however merely gives a measure of how well the "true" position of the regression line is known and not how accurately seawater temperature can be predicted from a single geochemical measurement. Therefore, in Table 3 we summarise the temperature uncertainty using confidence intervals and prediction intervals $(2 \sigma$; assuming that future observations have the same error variance as those used for fitting) that better characterises proxy reliability and discuss the results below.

\subsubsection{All biogenic aragonites}

Combination of our aragonitic stylasterid and scleractinian coral $\mathrm{Li} / \mathrm{Mg}$ data with published biogenic aragonite $\mathrm{Li} / \mathrm{Mg}$ temperature calibrations (Equation (7)) offers an improvement in confidence intervals to $\pm 0.25^{\circ} \mathrm{C}$ (for a $\mathrm{Li} / \mathrm{Mg}$ value of $4 \mathrm{mmol} / \mathrm{mol}$ ) over $\mathrm{Li} / \mathrm{Mg}$ calibration data from previous studies alone (Fig. 1). Despite the exponential fit now explaining more of the variance, addition of our data only slightly reduces prediction interval uncertainty for "All aragonite" $\mathrm{Li} / \mathrm{Mg}$, which is now $\pm 3.4^{\circ} \mathrm{C}$. This result suggests that our data, and that of previous studies, are adequately capturing the variance about the exponential relationship, thus giving a representative estimate of the ability of the $\mathrm{Li} / \mathrm{Mg}$ proxy to reproduce past seawater temperatures.

\subsubsection{Aragonitic stylasterid corals}

As this is the first study of stylasterid trace metal chemistry, we have only the 16 observations in this study with which to characterise the aragonitic stylasterid relationships with temperature (Equations (4) and (6)). With fewer observations, these temperature calibrations on their own have wider confidence intervals than that of "All aragonites" at more than $\pm 0.6^{\circ} \mathrm{C}$. Despite this, the prediction intervals of $\pm 5.3^{\circ} \mathrm{C}$ show the aragonitic stylasterid $\mathrm{Sr} / \mathrm{Ca}$ linear temperature calibration (Equation (4)) to be a useful paleo-temperature monitor. The narrower prediction interval of aragonitic stylasterid $\mathrm{Li} / \mathrm{Mg}$ however, suggests that this has the most potential as a precise seawater temperature proxy with a reconstruction uncertainty of just $\pm 2.3{ }^{\circ} \mathrm{C}$ (Equation (6)). This result further implies that the removal of growth rate effects by ratioing $\mathrm{Li}$ to $\mathrm{Mg}$ is more robust for organisms that precipitate their skeletal carbonate closer to equilibrium with seawater.

\subsubsection{High-Mg calcites}

We propose a new exponential relationship of $\mathrm{Li} / \mathrm{Mg}$ to temperature in high-Mg calcites that includes calcitic corals and CCA (Equation (8)). Prediction intervals of $\pm 3.4{ }^{\circ} \mathrm{C}$ for this relationship suggest an improvement in temperature reproducibility over the linear relationship proposed for CCA grown in culture alone (Anagnostou et al., 2019). This "all high-Mg calcites" relationship is determined using data from nine discrete temperature conditions, without overlap between biological groups (i.e. stylasterids low temperature, CCA and Corallium high temperature). Further interrogation of this relationship is required to test its robustness across the full seawater temperature range and in particular the robustness of inter-species offsets between high-Mg calcite organisms.

\subsection{Conclusions}

Depending on their skeletal calcium carbonate polymorph, we find stylasterid coral geochemistry to be similar to other biogenic 
aragonites or high-Mg calcite counterparts. If composed of just one carbonate polymorph (i.e. solely aragonite or high-Mg calcite) stylasterid corals have both $\delta^{18} \mathrm{O}$ values close to equilibrium with seawater and little variability in $\delta^{18} \mathrm{O}, \mathrm{Sr} / \mathrm{Ca}$, and $\mathrm{Li} / \mathrm{Mg}$ between solid sample replicates from a single specimen. This strongly suggests that stylasterids perform little modification of local/internal seawater. Such open system calcification means that stylasterid corals offer a wide array of accurate temperature proxy capabilities beyond that of scleractinia.

Our new data from modern cold-water coral specimens redress the balance of previous temperature calibrations biased towards shallow-water zooxanthellate corals. In accordance with previous studies, we find poor correlation between scleractinian $\delta^{18} \mathrm{O}$ and $\mathrm{Sr} / \mathrm{Ca}$ with seawater temperature. With the exception of stylasterid corals, we therefore do not advocate the use of $\delta^{18} \mathrm{O}$ and $\mathrm{Sr} / \mathrm{Ca}$ ratios for paleo-temperature reconstructions using multiple coldwater coral individuals.

Our coral Li/Mg data show the strongest relationship with temperature; thus, we are better able to characterise the Li/Mg exponential relationship in biogenic aragonites for seawater temperatures below $16^{\circ} \mathrm{C}$. Our data further suggest that this calibration is universal to all biogenic aragonites, demonstrating $\mathrm{Li} / \mathrm{Mg}$ to be an extremely accurate and versatile temperature proxy, particularly in aragonitic Stylasteridae corals. We show that a similar exponential temperature dependency also exists for $\mathrm{Li} / \mathrm{Mg}$ ratios across all high-Mg calcitic taxa. Future implementation of these proxies for paleo-temperature estimates in fossilised biogenic carbonates, will therefore deepen our knowledge of the thermal history of the ocean.

\section{Declaration of competing interest}

The authors declare that they have no known competing financial interests or personal relationships that could have appeared to influence the work reported in this paper.

\section{Acknowledgements}

We acknowledge the crew and researchers on board the research vessels that obtained the samples for this study. AL0508 was supported by The Dalio Explore Fund. We also acknowledge the Galápagos National Park directorate for permission to map and collect submarine rock and biological samples (PC-44-15), and the Charles Darwin Foundation for facilitating scientific collaboration in the Galápagos. We thank C. Coath, C. Taylor, M. Knaak, Q. Liu, R. Greenop, E. Littley, and J. Crumpton-Banks for their help with laboratory work. This is publication number 175 of Huinay Scientific Field Station. Funding was provided by an Antarctic Bursary awarded to J.A.S., ERC and NERC grants awarded to L.F.R. (278705, NE/S001743/1, NE/R005117/1) and L.F.R. and J.W.B.R. (NE/N003861/1), and a NERC Stable isotope Grant.

\section{Appendix A. Supplementary material}

Supplementary material related to this article can be found online at https://doi.org/10.1016/j.epsl.2020.116412.

\section{References}

Adkins, J.F., Boyle, E.A., Curry, W.B., Lutringer, A., 2003. Stable isotopes in deep-sea corals and a new mechanism for "vital effects". Geochim. Cosmochim. Acta 67, 1129-1143.

Al-Horani, F.A., Al-Moghrabi, S.M., de Beer, D., 2003. Microsensor study of photosynthesis and calcification in the scleractinian coral, Galaxea fascicularis: active internal carbon cycle. J. Exp. Mar. Biol. Ecol. 288, 1-15.

Anagnostou, E., Sherrell, R.M., Gagnon, A., LaVigne, M., Field, M.P., McDonough, W.F. 2011. Seawater nutrient and carbonate ion concentrations recorded as $\mathrm{P} / \mathrm{Ca}$,
$\mathrm{Ba} / \mathrm{Ca}$, and $\mathrm{U} / \mathrm{Ca}$ in the deep-sea coral Desmophyllum dianthus. Geochim. Cosmochim. Acta 75, 2529-2543.

Anagnostou, E., Williams, B., Westfield, I., Foster, G.L., Ries, J.B., 2019. Calibration of the $\mathrm{pH}-\delta^{11} \mathrm{~B}$ and temperature- $\mathrm{Mg} / \mathrm{Li}$ proxies in the long-lived high-latitude crustose coralline red alga Clathromorphum compactum via controlled laboratory experiments. Geochim. Cosmochim. Acta 254, 142-155.

Anand, P., Elderfield, H., Conte, M.H., 2003. Calibration of $\mathrm{Mg} / \mathrm{Ca}$ thermometry in planktonic foraminifera from a sediment trap time series. Paleoceanography 18 1050.

Andersson, E.R., Stewart, J.A., Work, T.M., Woodley, C.M., Schock, T.B., Day, R.D., 2020 Morphological, elemental, and boron isotopic insights into pathophysiology of diseased coral growth anomalies. Sci. Rep. 10, 8252.

Beck, J.W., Edwards, R.L., Ito, E., Taylor, F.W., Recy, J., Rougerie, F., Joannot, P., Henin, C., 1992. Sea-surface temperature from coral skeletal strontium/calcium ratios. Science 257, 644-647.

Boyle, E.A. 1981. Cadmium, zinc, copper, and barium in foraminifera tests. Earth Planet. Sci. Lett. 53, 11-35.

Broecker, W.S., 1982. Glacial to interglacial changes in ocean chemistry. Prog Oceanogr. 11, 151-197.

Bryan, S.P., Marchitto, T.M., 2008. Mg/Ca-temperature proxy in benthic foraminifera: new calibrations from the Florida Straits and a hypothesis regarding $\mathrm{Mg} / \mathrm{Li}$. Paleoceanography 23, 1-17.

Cairns, S.D., 2011. Global diversity of the Stylasteridae (Cnidaria: Hydrozoa: Athecatae). PLoS ONE 6, e21670.

Cairns, S.D., Macintyre, I.G., 1992. Phylogenetic implications of calcium carbonate mineralogy in the Stylasteridae (Cnidaria: Hydrozoa). Palaios.

Case, D.H., Robinson, L.F., Auro, M.E., Gagnon, A.C., 2010. Environmental and biological controls on $\mathrm{Mg}$ and $\mathrm{Li}$ in deep-sea scleractinian corals. Earth Planet. Sci. Lett. 300, 215-225.

Chaabane, S., López Correa, M., Ziveri, P., Trotter, J., Kallel, N., Douville, E., McCulloch, M., Taviani, M., Linares, C., Montagna, P., 2019. Elemental systematics of the calcitic skeleton of Corallium rubrum and implications for the $\mathrm{Mg} / \mathrm{Ca}$ temperature proxy. Chem. Geol. 524, 237-258.

Chen, S., Gagnon, A.C., Adkins, J.F., 2018. Carbonic anhydrase, coral calcification and a new model of stable isotope vital effects. Geochim. Cosmochim. Acta 236, 179-197.

Cheng, H., Adkins, J., Edwards, R.L., Boyle, E.A., 2000. U-Th dating of deep-sea corals Geochim. Cosmochim. Acta 64, 2401-2416.

Cobb, K.M., Charles, C.D., Cheng, H., Edwards, R.L., 2003. El Niño/Southern Oscillation and tropical Pacific climate during the last millennium. Nature 424, 271-276.

Cohen, A.L., Layne, G.D., Hart, S.R., Lobel, P.S., 2001. Kinetic control of skeletal Sr/Ca in a symbiotic coral: implications for the paleotemperature proxy. Paleoceanography $16,20-26$.

Correa, M.L., Montagna, P., Vendrell-Simón, B., McCulloch, M., Taviani, M., 2010. Stable isotopes $\left(\delta^{18} \mathrm{O}\right.$ and $\left.\delta^{13} \mathrm{C}\right)$, trace and minor element compositions of Recent scleractinians and Last Glacial bivalves at the Santa Maria di Leuca deepwater coral province, Ionian Sea. Deep-Sea Res., Part 2, Top. Stud. Oceanogr. 57, 471-486.

Crook, E.D., Potts, D., Rebolledo-Vieyra, M., Hernandez, L., Paytan, A., 2012. Calcifying coral abundance near low-pH springs: implications for future ocean acidification. Coral Reefs 31, 239-245.

Cuny-Guirriec, K., Douville, E., Reynaud, S., Allemand, D., Bordier, L., Canesi, M. Mazzoli, C., Taviani, M., Canese, S., McCulloch, M., Trotter, J., Rico-Esenaro, S.D., Sanchez-Cabeza, J.-A., Ruiz-Fernández, A.C., Carricart-Ganivet, J.P., Scott, P.M. Sadekov, A., Montagna, P., 2019. Coral Li/Mg thermometry: caveats and constraints. Chem. Geol. 523, 162-178.

DeCarlo, T.M., Gaetani, G.A., Cohen, A.L., Foster, G.L., Alpert, A.E., Stewart, J.A., 2016 Coral Sr-U thermometry. Paleoceanography 31, 626-638.

DeCarlo, T.M., Gaetani, G.A., Holcomb, M., Cohen, A.L., 2015. Experimental determination of factors controlling $\mathrm{U} / \mathrm{Ca}$ of aragonite precipitated from seawater: implications for interpreting coral skeleton. Geochim. Cosmochim. Acta 162, $151-165$.

Dellinger, M., West, A.J., Paris, G., Adkins, J.F., von Strandmann, P.A.E.P., Ullmann, C.V., Eagle, R.A., Freitas, P., Bagard, M.-L., Ries, J.B., 2018. The Li isotope composition of marine biogenic carbonates: patterns and mechanisms. Geochim. Cosmochim. Acta 236, 315-335.

Donald, H.K., Ries, J.B., Stewart, J.A., Fowell, S.E., Foster, G.L., 2017. Boron isotope sensitivity to seawater $\mathrm{pH}$ change in a species of Neogoniolithon coralline red alga. Geochim. Cosmochim. Acta 217, 240-253.

Fowell, S.E., Sandford, K., Stewart, J.A., Castillo, K.D., Ries, J.B., Foster, G.L., 2016 Intra-reef variations in $\mathrm{Li} / \mathrm{Mg}$ and $\mathrm{Sr} / \mathrm{Ca}$ sea surface temperature proxies in the Caribbean reef-building coral Siderastrea siderea. Paleoceanography 31 $1315-1329$.

Furla, P., Galgani, I., Durand, I., Allemand, D., 2000. Sources and mechanisms of inorganic carbon transport for coral calcification and photosynthesis. J. Exp. Biol. 203, 3445-3457.

Gaetani, G.A., Cohen, A.L., Wang, Z., Crusius, J., 2011. Rayleigh-based, multi-element coral thermometry: a biomineralization approach to developing climate proxies. Geochim. Cosmochim. Acta 75, 1920-1932. 
Gagan, M.K., Dunbar, G.B., Suzuki, A., 2012. The effect of skeletal mass accumulation in Porites on coral $\mathrm{Sr} / \mathrm{Ca}$ and $\delta^{18} \mathrm{O}$ paleothermometry. Paleoceanography 27, PA1203.

Gagnon, A.C., Adkins, J.F., Fernandez, D.P., Robinson, L.F., 2007. Sr/Ca and $\mathrm{Mg} / \mathrm{Ca}$ vital effects correlated with skeletal architecture in a scleractinian deep-sea coral and the role of Rayleigh fractionation. Earth Planet. Sci. Lett. 261, 280-295.

Guo, W., 2020. Kinetic clumped isotope fractionation in the DIC- $\mathrm{H}_{2} \mathrm{O}-\mathrm{CO}_{2}$ system: patterns, controls, and implications. Geochim. Cosmochim. Acta 268, 230-257.

Hall, J.M., Chan, L.H., 2004. Li/Ca in multiple species of benthic and planktonic foraminifera: thermocline, latitudinal, and glacial-interglacial variation. Geochim. Cosmochim. Acta 68, 529-545.

Hathorne, E.C., Felis, T., Suzuki, A., Kawahata, H., Cabioch, G., 2013a. Lithium in the aragonite skeletons of massive Porites corals: a new tool to reconstruct tropical sea surface temperatures. Paleoceanography 28, 143-152.

Hathorne, E.C., Gagnon, A., Felis, T., Adkins, J., Asami, R., Boer, W., Caillon, N., Case, D., Cobb, K.M., Douville, E., deMenocal, P., Eisenhauer, A., Garbe-Schönberg D., Geibert, W., Goldstein, S., Hughen, K., Inoue, M., Kawahata, H., Kölling, M., Cornec, F.L., Linsley, B.K., McGregor, H.V., Montagna, P., Nurhati, I.S., Quinn, T.M., Raddatz, J., Rebaubier, H., Robinson, L., Sadekov, A., Sherrell, R., Sinclair, D. Tudhope, A.W., Wei, G., Wong, H., Wu, H.C., You, C.-F., 2013b. Interlaboratory study for coral $\mathrm{Sr} / \mathrm{Ca}$ and other element/Ca ratio measurements. Geochem. Geophys. Geosyst. 14, 3730-3750.

Holcomb, M., DeCarlo, T.M., Gaetani, G.A., McCulloch, M., 2016. Factors affecting B/C ratios in synthetic aragonite. Chem. Geol. 437, 67-76.

Jurikova, H., Liebetrau, V., Raddatz, J., Fietzke, J., Trotter, J., Rocholl, A., Krause, S. McCulloch, M., Rüggeberg, A., Eisenhauer, A., 2019. Boron isotope composition of the cold-water coral Lophelia pertusa along the Norwegian margin: zooming into a potential $\mathrm{pH}$-proxy by combining bulk and high-resolution approaches Chem. Geol. 513, 143-152.

Key, R.M., Kozyr, A., Sabine, C.L., Lee, K., Wanninkhof, R., Bullister, J.L., Feely, R.A Millero, F.J., Mordy, C., Peng, T.H., 2004. A global ocean carbon climatology: results from global data analysis project (GLODAP). Glob. Biogeochem. Cycles 18.

Knutson, D.W., Buddemeier, R.W., Smith, S.V., 1972. Coral chronometers: seasonal growth bands in reef corals. Science 177, 270

Locarnini, R.A., Mishonov, A.V., Antonov, J.I., Boyer, T.P., Garcia, H.E., Baranova, O.K. Zweng, M.M., Paver, C.R., Reagan, J.R., Johnson, D.R., Hamilton, M., Seidov, D. 2013. World Ocean Atlas 2013, Volume 1: Temperature. In: Levitus, S. (Ed.), NOAA Atlas NESDIS.

Marchitto, T.M., Bryan, S.P., Doss, W., McCulloch, M.T., Montagna, P., 2018. A simple biomineralization model to explain $\mathrm{Li}, \mathrm{Mg}$, and $\mathrm{Sr}$ incorporation into aragonitic foraminifera and corals. Earth Planet. Sci. Lett. 481, 20-29.

Marriott, C.S., Henderson, G.M., Belshaw, N.S., Tudhope, A.W., 2004. Temperature dependence of $\delta^{7} \mathrm{Li}, \delta^{44} \mathrm{Ca}$ and $\mathrm{Li} / \mathrm{Ca}$ during growth of calcium carbonate. Earth Planet. Sci. Lett. 222, 615-624.

McConnaughey, T., 1989. ${ }^{13} \mathrm{C}$ and ${ }^{18} \mathrm{O}$ isotopic disequilibrium in biological carbonates, I: patterns. Geochim. Cosmochim. Acta 53, 151-162.

McCulloch, M.T., Tudhope, A.W., Esat, T.M., Mortimer, G.E., Chappell, J., Pillans, B., Chivas, A.R., Omura, A., 1999. Coral record of equatorial sea-surface temperatures during the Penultimate Deglaciation at Huon Peninsula. Science 283, 202.

Montagna, P., McCulloch, M., Douville, E., López Correa, M., Trotter, J., RodolfoMetalpa, R., Dissard, D., Ferrier-Pagès, C., Frank, N., Freiwald, A., Goldstein, S.
Mazzoli, C., Reynaud, S., Rüggeberg, A., Russo, S., Taviani, M., 2014. Li/Mg systematics in scleractinian corals: calibration of the thermometer. Geochim. Cosmochim. Acta 132, 288-310.

Poggemann, D.-W., Hathorne, E.C., Nürnberg, D., Frank, M., Bruhn, I., Reißig, S., Bahr, A., 2017. Rapid deglacial injection of nutrients into the tropical Atlantic via Antarctic Intermediate Water. Earth Planet. Sci. Lett. 463, 118-126.

Raddatz, J., Liebetrau, V., Rüggeberg, A., Hathorne, E., Krabbenhöft, A., Eisenhauer, A., Böhm, F., Vollstaedt, H., Fietzke, J., López Correa, M., Freiwald, A., Dullo, W.C., 2013. Stable $\mathrm{Sr}$-isotope, $\mathrm{Sr} / \mathrm{Ca}, \mathrm{Mg} / \mathrm{Ca}, \mathrm{Li} / \mathrm{Ca}$ and $\mathrm{Mg} / \mathrm{Li}$ ratios in the scleractinian cold-water coral Lophelia pertusa. Chem. Geol. 352, 143-152.

Rae, J.W.B., Foster, G.L., Schmidt, D.N., Elliott, T., 2011. Boron isotopes and B/Ca in benthic foraminifera: proxies for the deep ocean carbonate system. Earth Planet. Sci. Lett. 302, 403-413.

Roberts, J., Gottschalk, J., Skinner, L.C., Peck, V.L., Kender, S., Elderfield, H., Waelbroeck, C., Vázquez Riveiros, N., Hodell, D.A., 2016. Evolution of South Atlantic density and chemical stratification across the last deglaciation. Proc. Natl. Acad. Sci. USA 113, 514

Roberts, J.M., Wheeler, A.J., Freiwald, A., 2006. Reefs of the deep: the biology and geology of cold-water coral ecosystems. Science 312, 543-547.

Ross, C.L., DeCarlo, T.M., McCulloch, M.T., 2019. Calibration of Sr/Ca, Li/Mg and Sr-U Paleothermometry in branching and Foliose corals. Paleoceanogr. Paleoclimatol. 34, 1271-1291.

Samperiz, A., Robinson, L.F., Stewart, J.A., Strawson, I., Leng, M.J., Ciscato, E.R., Santodomingo, N., Hendry, K.R., Huveene, V.A.I., Rosenheim, B.E., 2020. Stylasterid corals: a new paleotemperature archive. Earth Planet. Sci. Lett. https:// doi.org/10.1016/j.epsl.2020.116407. In press.

Schmidt, G.A., Bigg, G.R., Rohling, E.J., 1999. Global Seawater Oxygen-18 Database v1. 22. NASA.

Sinclair, D.J., Risk, M.J., 2006. A numerical model of trace-element coprecipitation in a physicochemical calcification system: application to coral biomineralization and trace-element 'vital effects'. Geochim. Cosmochim. Acta 70, 3855-3868.

Spooner, P.T., Guo, W., Robinson, L.F., Thiagarajan, N., Hendry, K.R., Rosenheim, B.E., Leng, M.J., 2016. Clumped isotope composition of cold-water corals: a role for vital effects? Geochim. Cosmochim. Acta 179, 123-141.

Stewart, J.A., Anagnostou, E., Foster, G.L., 2016. An improved boron isotope pH proxy calibration for the deep-sea coral Desmophyllum dianthus through sub-sampling of fibrous aragonite. Chem. Geol. 447, 148-160.

Stewart, J.A., Christopher, S.J., Day, R.D., 2015. New carbonate standard reference materials for boron isotope geochemistry (abstract). In: AGU Fall Meeting. San Francisco, USA

Thiagarajan, N., Subhas, A.V., Southon, J.R., Eiler, J.M., Adkins, J.F., 2014. Abrupt preBølling-Allerød warming and circulation changes in the deep ocean. Nature 511, 75.

Wang, Z., Gaetani, G., Liu, C., Cohen, A., 2013. Oxygen isotope fractionation between aragonite and seawater: developing a novel kinetic oxygen isotope fractionation model. Geochim. Cosmochim. Acta 117, 232-251.

Watson, E.B., 2004. A conceptual model for near-surface kinetic controls on the trace-element and stable isotope composition of abiogenic calcite crystals. Geochim. Cosmochim. Acta 68, 1473-1488. 